\title{
A new genus Allodiatrype, five new species and a new host record of diatrypaceous fungi from palms (Arecaceae)
}

\section{Konta $\mathrm{S}^{1,2,3}$, Maharachchikumbura $\mathrm{SSN}^{4}$, Senanayake $\mathrm{IC}^{5}$, McKenzie EHC ${ }^{6}$, Stadler $\mathbf{M}^{7}$, Boonmee $S^{1,2}$, Phookamsak $R^{1,3,11,12}$, Jayawardena $\mathbf{R S}^{1,2}$, Senwanna $\mathrm{C}^{1,8}$, Hyde $\mathrm{KD}^{1,3,12}$, Elgorban $\mathrm{AM}^{9,10}$ and Eungwanichayapant $\mathbf{P D}^{2 *}$}

\footnotetext{
${ }^{1}$ Center of Excellence in Fungal Research, Mae Fah Luang University, Chiang Rai 57100, Thailand

${ }^{2}$ School of Science, Mae Fah Luang University, Chiang Rai 57100, Thailand

${ }^{3}$ Centre for Mountain Futures (CMF), Kunming Institute of Botany, Chinese Academy of Sciences, Kunming 650201, Yunnan, People's Republic of China

${ }^{4}$ School of Life Science and Technology, University of Electronic Science and Technology of China, Chengdu, 611731, People's Republic of China

${ }^{5}$ Shenzhen Key Laboratory of Microbial Genetic Engineering, College of Life Science and Oceanography, Shenzhen University, 3688, Nanhai Avenue, Nanshan, Shenzhen 518055, People's Republic of China

${ }^{6}$ Manaaki Whenua Landcare Research, Private Bag 92170, Auckland, New Zealand

${ }^{7}$ Department of Microbial Drugs, Helmholtz-Zentrum für Infektionsforschung GmbH, Inhoffenstrasse 7, 38124 Brunswick, Germany

${ }^{8}$ Department of Entomology and Plant Pathology, Faculty of Agriculture, Chiang Mai University, Chiang Mai 50200, Thailand

${ }^{9}$ Center of Excellence in Biotechnology Research, King Saud University P.O. Box. 2455, Riyadh 11451, Saudi Arabia

${ }^{10}$ Department of Botany and Microbiology, College of Sciences, King Saud University P.O. Box. 2455, Riyadh 11451, Saudi Arabia, Riyadh, Saudi Arabia

${ }^{11}$ Key Laboratory for Plant Diversity and Biogeography of East Asia, Kunming Institute of Botany, Chinese Academy of Sciences, Kunming 650201, Yunnan, People's Republic of China

${ }^{12}$ East and Central Asia Regional Office, World Agroforestry Centre (ICRAF), Kunming 650201, Yunnan, People's Republic of China
}

Konta S, Maharachchikumbura SSN, Senanayake IC, McKenzie EHC, Stadler M, Boonmee S, Phookamsak R, Jayawardena RS, Senwanna C, Hyde KD, Elgorban AM, Eungwanichayapant PD 2020 - A new genus Allodiatrype, five new species and a new host record of diatrypaceous fungi from palms (Arecaceae). Mycosphere 11(1), 239-268, Doi 10.5943/mycosphere/11/1/4

\begin{abstract}
Diatrypaceous fungi on palms (Arecaceae) in Thailand were collected and identified based on morphological characteristics as well as combined DNA sequence analyses (ITS and TUB2). One new genus Allodiatrype, and five new species, Allocryptovalsa elaeidis, Allodiatrype arengae, A. elaeidicola, A. elaeidis and Diatrypella elaeidis are introduced. A checklist of Diatrypaceae occurring on palms (Arecaceae) and Thai diatrypaceous fungi is also provided.
\end{abstract}

Keywords - 6 novel taxa - Diatrypaceae - morphology - palm fungi - phylogeny - Thai fungi Xylariales

\section{Introduction}

The ascomycete family Diatrypaceae Nitschke was introduced and typified by Diatrype Fr. (Nitschke 1869). Diatrypaceous taxa have a worldwide distribution in aquatic and terrestrial habitats (Chlebicki 1986, Glawe \& Jacobs 1987, Carmarán et al. 2006, de Almeida et al. 2016, 
Dayarathne et al. 2016, Mayorquin et al. 2016, Senwanna et al. 2017, Shang et al. 2017, 2018, Moyo et al. 2018a). Most genera in Diatrypaceae are wood-inhabiting saprobes (Trouillas et al. 2011, Grassi et al. 2014, Mehrabi et al. 2016, Hyde et al. 2019, Phookamsak et al. 2019); some are plant pathogens causing cankers, dieback and grapevine trunk diseases (caused by Anthostoma decipiens (DC.) Nitschke, Cryptovalsa ampelina (Nitschke) Fuckel, Eutypa lata (Pers.) Tul. \& C. Tul., Eutypella citricola Speg, E. microtheca Trouillas, W.M. Pitt \& Gubler, E. parasitica R.W. Davidson \& R.C. Lorenz (Mostert et al. 2004, Jurc et al. 2006, Luque et al. 2006, 2012, Pitt et al. 2013, Rolshausen et al. 2014, Paolinelli-Alfonso et al. 2015, Mayorquin et al. 2016, Kowalski \& Bednarz 2017, Moyo et al. 2018b); and some are endophytes such as Diatrypella frostii Peck, Libertella Desm. and Peroneutypa scoparia (Schwein.) Carmarán \& A.I. Romero (de Errasti et al. 2010, Vieira et al. 2011, Grassi et al. 2014).

The number of genera accepted in Diatrypaceae has changed over the years, and four genera have been introduced in the past ten years e.g. Allocryptovalsa Senwanna, Phookamsak \& K.D. Hyde, Diatrypasimilis JJ. Zhou \& Kohlm., Halodiatrype Dayarathne \& K.D. Hyde and Neoeutypella M. Raza, Q.J. Shang, Phookamsak \& L. Cai (Chalkley et al. 2010, Liu et al. 2015, Dayarathne et al. 2016, Senwanna et al. 2017, Phookamsak et al. 2019). Wijayawardene et al. (2017a) included 17 genera in the family; Phookamsak et al. (2019) introduced the new genus Neoeutypella, with two new species, while Hyde et al. (2019) introduced the new species Diatrypella delonicis R.H. Perera \& K.D. Hyde. Diatrypaceae is, however, relatively poorly studied with regard to potential biotechnological applications, such as the production of enzymes and beneficial secondary metabolites (Ciavatta et al. 2008, Grassi et al. 2014). The only species that have been studied thoroughly for bioactive compounds are the plant pathogenic Eutypa lata and Peroneutypa (syn: Eutypella) scoparia (Helaly et al. 2018).

Divergent time estimates and the evolution of major lineages in the Sordariomycetes have indicated that Diatrypaceae has an affinity to many families, such as Graphostromataceae M.E. Barr, J.D. Rogers \& Y.M. Ju, Hypoxylaceae DC., Lopadostomataceae Daranag. \& K.D. Hyde, Microdochiaceae Hern.-Restr., Crous \& J.Z. Groenew., Requienellaceae Boise., and Xylariaceae Tul. \& C. Tul. in the order Xylariales at 66-252 Mya, which is the same as the common divergence times of most of fungal families (Samarakoon et al. 2016, Hongsanan et al. 2017). Members of Diatrypaceae mostly have immersed to erumpent or rarely superficial, black or dark brown, eustromatic or pseudostromatic stromata, 8-spored or polysporous asci, hyaline to light brown, allantoid ascospores and a libertella-like asexual morph (Senanayake et al. 2015, Wijayawardene et al. 2017b). The concepts of segregating genera in Diatrypaceae are still rather confused as mentioned in Maharachchikumbura et al. (2016) and Shang et al. (2017, 2018). The placement of species in each genus of Diatrypaceae is very confused with many genera being polyphyletic (Shang et al. 2017, 2018). Hence, it is necessary to use both molecular (mostly based on ITS and TUB2 sequence data) and morphological data for the primary identification and classification of diatrypaceouse taxa.

The number of new microfungi that can be potentially discovered in Thailand is large (Hyde et al. 2018). In this study, we introduce a new genus, five new species, a new combination, new host and new geographical record for Diatrypaceae occurring on palms with morphological and phylogenetic evidence. Detailed descriptions, illustrations, and notes for each taxon are also provided.

\section{Materials \& Methods}

\section{Collection, isolation, and identification}

Fresh materials were collected from Thailand (Chiang Rai, Krabi, and Phang-Nga Provinces) during 2014-2015 on Arenga pinnata (Wurmb) Merr., Brahea armata S. Watson, Calamus L., and Elaeis guineensis Jacq. The taxa were identified based on morphological characteristics and DNA sequence data. Isolations and specimen examinations were conducted following the method provided by Konta et al. (2016). The specimens were deposited in the herbarium of Mae Fah Luang University (MFLU) and duplicated in the herbarium of Cryptogams, Kunming Institute of Botany 
Academia Sinica (KUN-HKAS). Cultures were deposited in Mae Fah Luang Culture Collection (MFLUCC) at Mae Fah Luang University, Chiang Rai, Thailand. Facesoffungi and Index Fungorum numbers were registered as outlined in Jayasiri et al. (2015) and Index Fungorum (2019).

\section{DNA extraction and amplification (PCR)}

Genomic DNA was extracted from fungal mycelium using the Biospin Fungus Genomic DNA extraction Kit (BioFlux, P.R. China) following the manufacturer's protocol. The partial nucleotide genes were subjected to PCR amplification and sequencing of internal transcribed spacer regions and intervening 5.8S rRNA gene (ITS) of the rDNA operon (White et al. 1990), 28S rRNA gene (LSU) (Vilgalys \& Hester 1990), 18S ribosomal RNA (SSU) (White et al. 1990), translation elongation factor 1-alpha (tef1) (Rehner \& Buckley 2005), RNA polymerase II second largest subunit (RPB2) (Liu et al. 1999, Sung et al. 2007) and $\beta$-tubulin (TUB2) (Glass \& Donaldson 1995, O’Donnell \& Cigelnik 1997). For primers and conditions see Table 1.

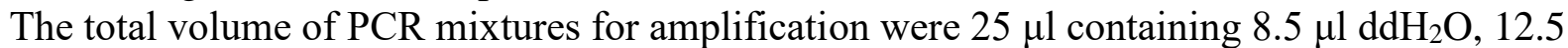
$\mu 12 \times$ Easy Taq PCR Super Mix (mixture of Easy Taq TM DNA Polymerase, dNTPs and optimized buffer (Beijing Trans Gen Biotech Co., Beijing, P.R. China), $2 \mu$ of DNA template, $1 \mu$ of each forward and reverse primers $(10 \mathrm{pM})$. The quality of PCR products was checked on $1 \%$ agarose gel electrophoresis stained with 4S green nucleic acid (Life Science Products \& Services, Shanghai, P.R. China). Purification and sequencing of PCR products were carried out by Sangon Biotech Co., Shanghai, P.R. China. The resulting fragments were sequenced in both directions with primers above. The DNA sequences generated were analyzed and consensus sequences were computed using SeqMan software.

Table 1 Details of genes/loci with PCR primers and PCR conditions.

\begin{tabular}{lll}
\hline \multicolumn{1}{c}{ Genes/loci } & \multicolumn{1}{c}{$\begin{array}{c}\text { PCR primers } \\
\text { (forward/reverse) }\end{array}$} & PCR conditions \\
\hline ITS, LSU, SSU, tef1 & $\begin{array}{l}\text { ITS5/ITS4, LR5/LR0R, } \\
\text { NS4/NS1, 983F/2218R }\end{array}$ & ${ }^{\mathrm{a}} ; 95^{\circ} \mathrm{C}: 30 \mathrm{~s}, 55^{\circ} \mathrm{C}: 50 \mathrm{~s}, 72^{\circ} \mathrm{C}: 30 \mathrm{~s}(35 \mathrm{cycles}) ;{ }^{\mathrm{c}}$ \\
\hline RPB2 & fRPB2-5f/fRPB2-7cR & b; $95^{\circ} \mathrm{C}: 1 \mathrm{~min}, 54^{\circ} \mathrm{C}: 2 \mathrm{~min}, 72{ }^{\circ} \mathrm{C}: 1.5 \mathrm{~min}(35 \mathrm{cycles}) ;{ }^{\mathrm{c}}$ \\
\hline TUB2 & T1/ Bt2b & b; $94^{\circ} \mathrm{C}: 1 \mathrm{~min}, 52^{\circ} \mathrm{C}: 1 \mathrm{~min}, 72{ }^{\circ} \mathrm{C}: 1.5 \mathrm{~min} ;{ }^{\mathrm{c}}$
\end{tabular}

${ }^{\mathrm{a}}$ Initiation step of $95^{\circ} \mathrm{C}: 3 \mathrm{~min} .{ }^{\mathrm{b}}$ Initiation step of $95^{\circ} \mathrm{C}: 5 \mathrm{~min} .{ }^{\mathrm{c}}$ Final elongation step of $72{ }^{\circ} \mathrm{C}: 10$ min and final hold at $4{ }^{\circ} \mathrm{C}$.

\section{Phylogenetic analysis}

The new sequences generated in this study were deposited in GenBank (Table 2) even if they were not used in the phylogenetic tree. The sequences generated in this study were analysed with additional sequences obtained from GenBank, based on BLAST searches and the literature (Hyde et al. 2019, Phookamsak et al. 2019). Sequences of the ITS and TUB2 were analysed individually and in combination. Only ITS and TUB2 sequence data were used in the analyses based on previous literature and other gene sequences were deposited in GenBank for future studies. Sequence alignments were carried out with MAFFT v.6.864b (Katoh \& Standley 2013) and alignments were manually improved where necessary. The single gene datasets were combined using Mega7 (Kumar et al. 2016). Data were converted from fasta to nexus and PHYLIP format with Alignment Transformation Environment online, https://sing.ei.uvigo.es/ALTER/ (Glez-Peña et al. 2010).

The phylogenetic methods used in this study included maximum likelihood analysis (ML) performed with RAxMl GUI v.1.0. (Stamatakis 2006, Silvestro \& Michalak 2011) and Bayesian posterior probabilities (BYPP). The latter method was performed at CIPRES using Bayesian analysis on XSEDE (v.3.2.6) as part of the "MrBayes on XSEDE" tool (Huelsenbeck \& Ronquist 2001, Miller et al. 2010). MrModelTest v. 2.2 was used to determine the best nucleotide substitution 
model settings for the alignment for each data partition of the Bayesian analysis (Nylander 2004). The model of evolution was performed using MrModelTest 2.2 (Nylander 2004) under the Akaike information criterion (AIC). GTR+I+G model was selected as the best-fit models of the combined dataset for maximum likelihood and Bayesian analysis (Nylander 2004). Bayesian posterior probabilities (BYPP) were determined by Markov Chain Monte Carlo sampling (MCMC) in MrBayes on XSEDE v.3.2.6. Six simultaneous Markov Chains were run for 3,000,000 generations and trees were sampled every 1,000th generation. MCMC heated chain was set with a "temperature" value of 0.20 . All sampled topologies beneath the asymptote $(25 \%)$ were discarded as part of a burn-in procedure; the remaining trees $(4,502)$ were used for calculating posterior probabilities in the majority rule consensus tree. BYPP equal to/or greater than 0.90 is given near to each node (Fig. 1). The phylogenetic trees were visualized in Fig Tree v1.4.0 (Rambaut 2006) and edited using Microsoft Office PowerPoint 2010 and Adobe Illustrator CS6 (Adobe Systems, USA). The alignments and respective phylogenetic trees were deposited in TreeBASE (submission ID: 25674).

\section{Results}

\section{Phylogenetic analyses}

Phylogenetic analyses of combined ITS and TUB2 sequence data based on ML and BYPP analyses indicate that the two tree topologies are similar. The dataset consists of 117 taxa for representative strains of species in Diatrypaceae. The total alignment length comprises 2,570 characters including gaps. The RAxML analysis resulted in a best scoring likelihood tree selected with a final ML optimization likelihood value of -22955.866702 which is represented in Fig. 1 . The final likelihood tree was evaluated and optimized under GAMMA model parameters, with 1,547 distinct alignment patterns and $65.11 \%$ of undetermined characters or gaps. Bayesian posterior probabilities from MCMC were evaluated with a final average standard deviation of the split frequency of 0.011661 .

The phylogram generated from the combined ITS and TUB2 sequence data supports establishment of a new genus, five new species and six new host records of diatrypaceous fungi within Diatrypaceae (Fig. 1). Allodiatrype species formed a basal clade to Neoeutypella, with Diatrype enteroxantha as the sister clade. Of the five new species, Allocryptovalsa elaeidis (MFLUCC 15-0707) formed a sister clade with A. polyspora (MFLUCC 17-0364, type species) and A. rabenhorstii with high bootstrap support within the genus Allocryptovalsa (100\% ML, 1.00 BYPP). Allodiatrype arengae (MFLUCC 15-0713) clustered with A. elaeidis with high bootstrap support (100\% ML, 1.00 BYPP). Allodiatrype elaeidis (MFLUCC 15-0708) clustered with A. elaeidicola with 61\% ML bootstrap support. Allodiatrype elaeidicola (MFLUCC 15-0737) clustered with A. thailandica with low bootstrap support. Diatrypella elaeidis (MFLUCC 15-0279) is sister to Diatrypella delonicis (MFLUCC 15-1014) with low bootstrap support (61\% ML). Of the new hosts and geographical records, Allodiatrype thailandica (MFLUCC 15-0711) appeared related to the generic type of the genus (MFLUCC 14-1210). Our new isolate of Diatrypella (MFLUCC 17-0368) grouped with ex-type strain of D. heveae (MFLUCC 15-0274) with high bootstrap support (100\% ML, 1.00 BYPP).

Table 2 GenBank accession numbers of sequences used in phylogenetic analyses.

\begin{tabular}{lllll}
\hline \multirow{2}{*}{ Species } & \multicolumn{1}{c}{ Strains } & \multicolumn{2}{c}{$\begin{array}{c}\text { GenBank accession } \\
\text { numbers }\end{array}$} & \multirow{2}{*}{ References } \\
\cline { 3 - 4 } & & ITS & TUB2 & \\
\hline Allocryptovalsa cryptovalsoidea & HVFIG02 & HQ692573 & HQ692524 & Trouillas et al. (2011) \\
Allocryptovalsa cryptovalsoidea & HVFIG05 & HQ692574 & HQ692525 & Trouillas et al. (2011) \\
Allocryptovalsa elaeidis & MFLUCC 15-0707 & MN308410 & MN340296 & This study \\
Allocryptovalsa polyspora ${ }^{\mathbf{T}}$ & MFLUCC 17-0364 & MF959500 & MG334556 & Senwanna et al. (2017) \\
Allocryptovalsa rabenhorstii & WA07CO & HQ692620 & HQ692522 & Trouillas et al. (2011) \\
\hline
\end{tabular}


Table 2 Continued.

\begin{tabular}{|c|c|c|c|c|}
\hline \multirow[t]{2}{*}{ Species } & \multirow[t]{2}{*}{ Strains } & \multicolumn{2}{|c|}{$\begin{array}{c}\text { GenBank accession } \\
\text { numbers }\end{array}$} & \multirow[t]{2}{*}{ References } \\
\hline & & ITS & TUB2 & \\
\hline Allocryptovalsa rabenhorstii & WA08CB & HQ692619 & HQ692523 & Trouillas et al. (2011) \\
\hline Allodiatrype arengae $^{\mathrm{T}}$ & MFLUCC 15-0713 & MN308411 & MN340297 & This study \\
\hline Allodiatrype elaeidicola & MFLUCC 15-0737a & MN308415 & MN340299 & This study \\
\hline Allodiatrype elaeidicola & MFLUCC 15-0737b & MN308416 & - & This study \\
\hline Allodiatrype elaeidis & MFLUCC 15-0708a & MN308412 & MN340298 & This study \\
\hline Allodiatrype elaeidis & MFLUCC 15-0708b & MN308413 & - & This study \\
\hline $\begin{array}{l}\text { Allodiatrype thailandica } \\
\text { 'Diatrype thailandica' }\end{array}$ & MFLUCC 14-1210 & KU315392 & - & Li et al. (2016) \\
\hline Allodiatrype thailandica & MFLUCC 15-0711 & MN308414 & - & This study \\
\hline Anthostoma decipiens ${ }^{\mathbf{T}}$ & IPV-FW349 & AM399021 & AM920693 & Unpublished \\
\hline Anthostoma decipiens ${ }^{\mathbf{T}}$ & JL567 & JN975370 & JN975407 & Luque et al. (2012) \\
\hline Cryptosphaeria eunomia $^{\mathbf{T}}$ & C1C, CBS 216.87 & AJ302417 & - & Acero et al. (2004) \\
\hline Cryptosphaeria eunomia $^{\mathbf{T}}$ & C5C, CBS 223.87 & AJ302421 & - & Acero et al. (2004) \\
\hline Cryptosphaeria ligniota & CBS 273.87 & KT425233 & KT425168 & Acero et al. (2004) \\
\hline Cryptosphaeria moravica & CBS 244.87 & HM164735 & HM164769 & Trouillas \& Gubler (2010) \\
\hline Cryptosphaeria pullmanensis & ATCC 52655 & KT425235 & KT425170 & Trouillas et al. (2015) \\
\hline Cryptosphaeria pullmanensis & HBPF24 & KT425202 & GQ294014 & Trouillas et al. (2010) \\
\hline Cryptosphaeria subcutanea & CBS 240.87 & KT425232 & KT425167 & Trouillas et al. (2015) \\
\hline Cryptosphaeria subcutanea & DSUB100A & KT425189 & KT425124 & Trouillas et al. (2015) \\
\hline Cryptovalsa ampelina & A001 & GQ293901 & GQ293972 & Trouillas et al. (2010) \\
\hline Cryptovalsa ampelina & DRO101 & GQ293902 & GQ293982 & Trouillas et al. (2010) \\
\hline Diatrype brunneospora & CNP01 & HМ581946 & HQ692478 & Trouillas et al. (2011) \\
\hline Diatrype bullata & UCDDCh400 & DQ006946 & DQ007002 & Rolshausen et al. (2006) \\
\hline Diatrype decorticata & 1056 & KU320621 & - & de Almeida et al. (2016) \\
\hline Diatrype bullata & D6C, CBS 215.87 & AJ302422 & - & Acero et al. (2004) \\
\hline Diatrype enteroxantha & HUEFS155114 & KM396617 & КТ003700 & de Almeida et al. (2016) \\
\hline Diatrype enteroxantha & HUEFS155116 & КМ396618 & KT022236 & de Almeida et al. (2016) \\
\hline Diatrype disciformis ${ }^{\mathbf{T}}$ & D21C, CBS 205.87 & AJ302437 & - & Acero et al. (2004) \\
\hline Diatrype disciformis ${ }^{\mathbf{T}}$ & D7M, GB5815 & AJ302423 & - & Acero et al. (2004) \\
\hline Diatrype macowaniana & D15C, CBS 214.87 & AJ302431 & - & Acero et al. (2004) \\
\hline Diatrype oregonensis & DPL200 & GQ293940 & GQ293999 & Trouillas et al. (2010) \\
\hline Diatrype palmicola & MFLUCC 11-0018 & KP744439 & - & Liu et al. (2015) \\
\hline Diatrype palmicola & MFLUCC 11-0020 & KP744438 & - & Liu et al. (2015) \\
\hline Diatrype polycocca & D16C, CBS 213.87 & AJ302432 & - & Acero et al. (2004) \\
\hline Diatrype spilomea & D17C & AJ302433 & & Acero et al. (2004) \\
\hline Diatrype stigma & DCASH200 & GQ293947 & GQ294003 & \\
\hline Diatrype stigma & UCD23-Oe & JX515704 & JX515670 & Úrbez-Torres et al. (2013) \\
\hline Diatrype undulata & D20C, CBS 271.87 & AJ302436 & - & Acero et al. (2004) \\
\hline Diatrype undulata & Olrim324 & AY354239 & - & Lygis et al. (2004) \\
\hline Diatrype whitmanensis & CDB011 & GQ293954 & GQ294010 & Trouillas et al. (2010) \\
\hline Diatrype whitmanensis & DCHES100 & GQ293951 & GQ294008 & Trouillas et al. (2010) \\
\hline Diatrypella atlantica & HUEFS 136873 & KM396614 & KR259647 & de Almeida et al. (2016) \\
\hline Diatrypella atlantica & HUEFS 194228 & KM396615 & KR363998 & de Almeida et al. (2016) \\
\hline Diatrypella banksiae & СРC 29118 & KY173402 & - & Crous et al. (2013) \\
\hline Diatrypella delonicis & MFLUCC 15-1014 & MH812994 & MH847790 & Hyde et al. (2019) \\
\hline Diatrypella delonicis & MFLU 16-1032 & MH812995 & MH847791 & Hyde et al. (2019) \\
\hline Diatrypella elaeidis & MFLUCC 15-0279 & MN308417 & MN340300 & This study \\
\hline Diatrypella favacea & Isolate 380 & KU320616 & - & de Almeida et al. (2016) \\
\hline Diatrypella frostii & UFMGCB 1917 & HQ377280 & - & Vieira et al. (2011) \\
\hline Diatrypella heveae & MFLUCC 17-0368 & MF959501 & MG334557 & Senwanna et al. (2017) \\
\hline Diatrypella heveae & MFLUCC 15-0274 & MN308418 & MN340301 & This study \\
\hline Diatrypella iranensis & KDQ18 & KM245033 & - & Mehrabi et al. (2015) \\
\hline Diatrypella major & Isolate 1058 & KU320613 & - & de Almeida et al. (2016) \\
\hline Diatrype oregonensis & CA117 & GQ293934 & GQ293996 & Trouillas et al. (2010) \\
\hline Diatrypella prominens & DL28A, ATCC 64182 & AJ302442 & - & Acero et al. (2004) \\
\hline Diatrype oregonensis & DPL200 & GQ293940 & GQ293999 & Trouillas et al. (2010) \\
\hline Diatrype prominens & & FJ430594 & - & Unpublished \\
\hline
\end{tabular}


Table 2 Continued.

\begin{tabular}{|c|c|c|c|c|}
\hline \multirow[t]{2}{*}{ Species } & \multirow[t]{2}{*}{ Strains } & \multicolumn{2}{|c|}{$\begin{array}{c}\text { GenBank accession } \\
\text { numbers }\end{array}$} & \multirow[t]{2}{*}{ References } \\
\hline & & ITS & TUB2 & \\
\hline Diatrype prominens & SBen212 & KU721868 & - & Lawrence et al. (2017) \\
\hline Diatrypella pulvinata & H048 & FR715523 & FR715495 & de Almeida et al. (2016) \\
\hline Diatrypella tectonae & MFLUCC 12-0172a & KY283084 & - & Shang et al. (2017) \\
\hline Diatrypella tectonae & MFLUCC 12-0172b & KY283085 & KY421043 & Shang et al. (2017) \\
\hline Diatrypella verruciformis ${ }^{\mathbf{T}}$ & UCROK1467 & JX144793 & JX174093 & Lynch et al. (2013) \\
\hline Diatrypella verruciformis ${ }^{\mathbf{T}}$ & UCROK754 & JX144783 & JX174083 & Lynch et al. (2013) \\
\hline Diatrypella vulgaris & HVFRA02 & HQ692591 & HQ692503 & Trouillas et al. (2011) \\
\hline Diatrypella vulgaris & HVGRF03 & HQ692590 & HQ692502 & Trouillas et al. (2011) \\
\hline Eutypa armeniacae & ATCC 28120 & DQ006948 & DQ006975 & Rolshausen et al. (2006) \\
\hline Eutypa astroidea & E49C, CBS 292.87 & AJ302458 & DQ006966 & Rolshausen et al. (2006) \\
\hline Eutypa flavovirens & E48C, CBS 272.87 & AJ302457 & DQ006959 & Rolshausen et al. (2006) \\
\hline Eutypa laevata & E40C CBS 291.87 & AJ302449 & - & Acero et al. (2004) \\
\hline Eutypa lata ${ }^{\mathbf{T}}$ & CBS 290.87 & HM164736 & HM164770 & Trouillas \& Gubler (2010) \\
\hline Eutypa lata ${ }^{\mathbf{T}}$ & EP18 & HQ692611 & HQ692501 & Trouillas et al. (2011) \\
\hline Eutypa lata ${ }^{\mathbf{T}}$ & RGA01 & HQ692614 & HQ692497 & Trouillas et al. (2011) \\
\hline Eutypa lejoplaca & CBS 248.87 & DQ006922 & DQ226974 & Rolshausen et al. (2006) \\
\hline Eutypa leptoplaca & CBS 287.87 & DQ006924 & DQ006961 & Rolshausen et al. (2006) \\
\hline Eutypa maura & CBS 219.87 & DQ006926 & DQ006967 & Rolshausen et al. (2006) \\
\hline Eutypa microasca & BAFC 51550 & KF964566 & KF964572 & Grassi et al. (2014) \\
\hline Eutypa sparsa & $38023 b$ & AY684220 & AY684201 & Trouillas \& Gubler (2004) \\
\hline Eutypella cerviculata $^{\mathbf{T}}$ & EL59C & AJ302468 & - & Acero et al. (2004) \\
\hline Eutypella cerviculata ${ }^{\mathbf{T}}$ & M68 & JF340269 & - & Arhipova et al. (2012) \\
\hline Eutypella citricola & HVGRF01 & HQ692579 & HQ692512 & Trouillas et al. (2011) \\
\hline Eutypella citricola & HVVIT07 & HQ692589 & HQ692521 & Trouillas et al. (2011) \\
\hline Eutypella leprosa & EL54C, CBS 276.87 & AJ302463 & - & Acero et al. (2004) \\
\hline Eutypella leprosa & Isolate 60 & KU320622 & - & de Almeida et al. (2016) \\
\hline Eutypella microtheca & ADEL200 & HQ692559 & HQ692527 & Trouillas et al. (2011) \\
\hline Eutypella microtheca & BCMX01 & KC405563 & KC405560 & Paolinelli-Alfonso et al. (2015) \\
\hline Eutypella parasitica & CBS 210.39 & DQ118966 & - & Jurc et al. (2006) \\
\hline Eutypella semicircularis & MP4669 & JQ517314 & - & Mehrabi et al. (2016) \\
\hline Eutypella vitis & UCD2291AR & HQ288224 & HQ288303 & Úrbez-Torres et al. (2012) \\
\hline Eutypella vitis & UCD2428TX & FJ790851 & GU294726 & Úrbez-Torres et al. (2009) \\
\hline Halodiatrype avicenniae & MFLUCC 15-0953 & KX573916 & KX573931 & Dayarathne et al. (2016) \\
\hline Halodiatrype salinicola $^{\mathbf{T}}$ & MFLUCC 15-1277 & KX573915 & KX573932 & Dayarathne et al. (2016) \\
\hline Kretzschmaria deusta & CBS 826.72 & KU683767 & KU684190 & U’Ren et al. (2016) \\
\hline Monosporascus cannonballus $\mathbf{T}^{\mathbf{T}}$ & CMM3646 & JX971617 & - & Unpublished \\
\hline Monosporascus cannonballus $^{\mathbf{T}}$ & ATCC 26931 & FJ430598 & - & Unpublished \\
\hline Neoeutypella baoshanensis ${ }^{\mathbf{T}}$ & EL51C, CBS 274.87 & AJ302460 & - & Acero et al. (2004) \\
\hline Neoeutypella baoshanensis $\mathbf{T}^{\mathbf{T}}$ & LC 12111 & MH822887 & MH822888 & Hyde et al. (2019) \\
\hline Pedumispora rhizophorae ${ }^{\mathbf{T}}$ & BCC 44877 & KJ888853 & - & Klaysuban et al. (2014) \\
\hline Pedumispora rhizophorae $^{\mathbf{T}}$ & BCC44878 & KJ888854 & - & Klaysuban et al. (2014) \\
\hline Peroneutypa alsophila & EL58C, CBS 250.87 & AJ302467 & - & Acero et al. (2004) \\
\hline Peroneutypa comosa & BAFC 393 & KF964568 & - & Grassi et al. (2014) \\
\hline Peroneutypa curvispora & HUEFS 136877 & КМ396641 & - & de Almeida et al. (2016) \\
\hline Peroneutypa diminutiasca & MFLUCC 17-2144 & MG873479 & - & Shang et al. (2018) \\
\hline Peroneutypa diminutispora & HUEFS 192196 & КМ396647 & - & de Almeida et al. (2016) \\
\hline Peroneutypa kochiana & EL53M & AJ302462 & - & Acero et al. (2004) \\
\hline Peroneutypa longiasca & MFLUCC 17-0371 & MF959502 & MG334558 & Senwanna et al. (2017) \\
\hline Peroneutypa mackenziei & MFLUCC 16-0072 & KY283083 & KY706363 & Shang et al. (2017) \\
\hline Peroneutypa mangrovei & NFCCI-4246 & MG844286 & MH094409 & Phookamsak et al. (2019) \\
\hline Peroneutypa rubiformis & MFLUCC 17-2142 & MG873477 & - & Shang et al. (2018) \\
\hline Peroneutypa scoparia & MFLUCC 11-0478 & KU940151 & - & Dai et al. (2016) \\
\hline Peroneutypa scoparia & MFLUCC 18-1111 & MK603519 & MK101307 & Hyde et al. (2019) \\
\hline Quaternaria quaternata & EL60C, CBS 278.87 & AJ302469 & - & Acero et al. (2004) \\
\hline Quaternaria quaternata & GNF13 & KR605645 & - & Mehrabi et al. (2016) \\
\hline Xylaria hypoxylon & CBS 122620 & AM993141 & KX271279 & Peršoh et al. (2009) \\
\hline
\end{tabular}

Note: Newly generated sequences are in bold; ${ }^{\mathbf{T}}$ denotes the type species of the genus. 


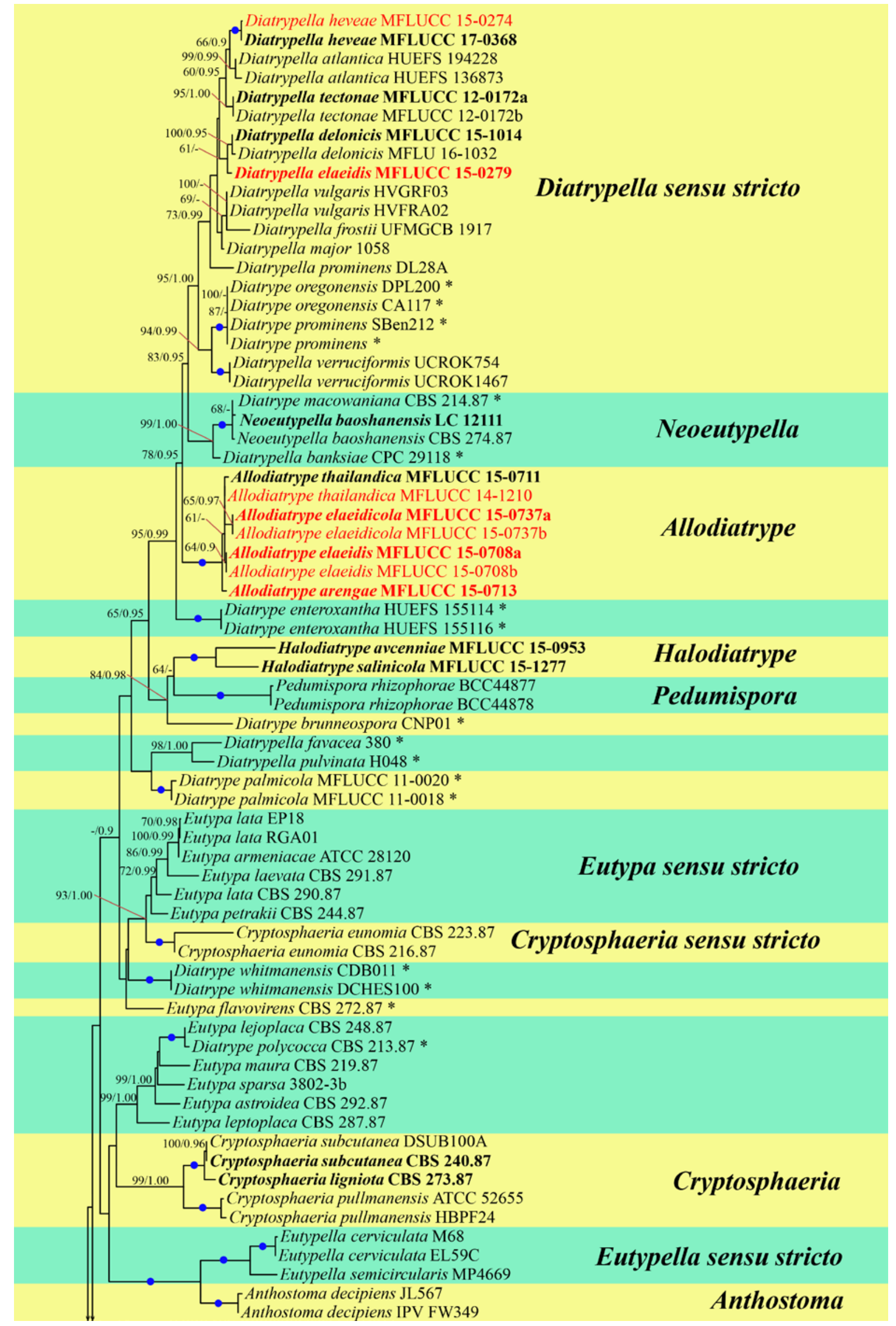

Figure 1 - Bayesian analyses the majority rule consensus tree of selected species in Diatrypaceae generated from combined ITS and TUB2 sequence data. Bootstrap support values for maximum 
likelihood (ML) greater than 50\%, and Bayesian posterior probabilities (BYPP) greater than 0.90 are given at the nodes. Branches with 100\% ML and 1.00 BYPP are shown with a blue dot. Ex-type strains are in bold. Newly generated sequences are in red. Novel taxa are in red bold. The asterisks represent unstable species.

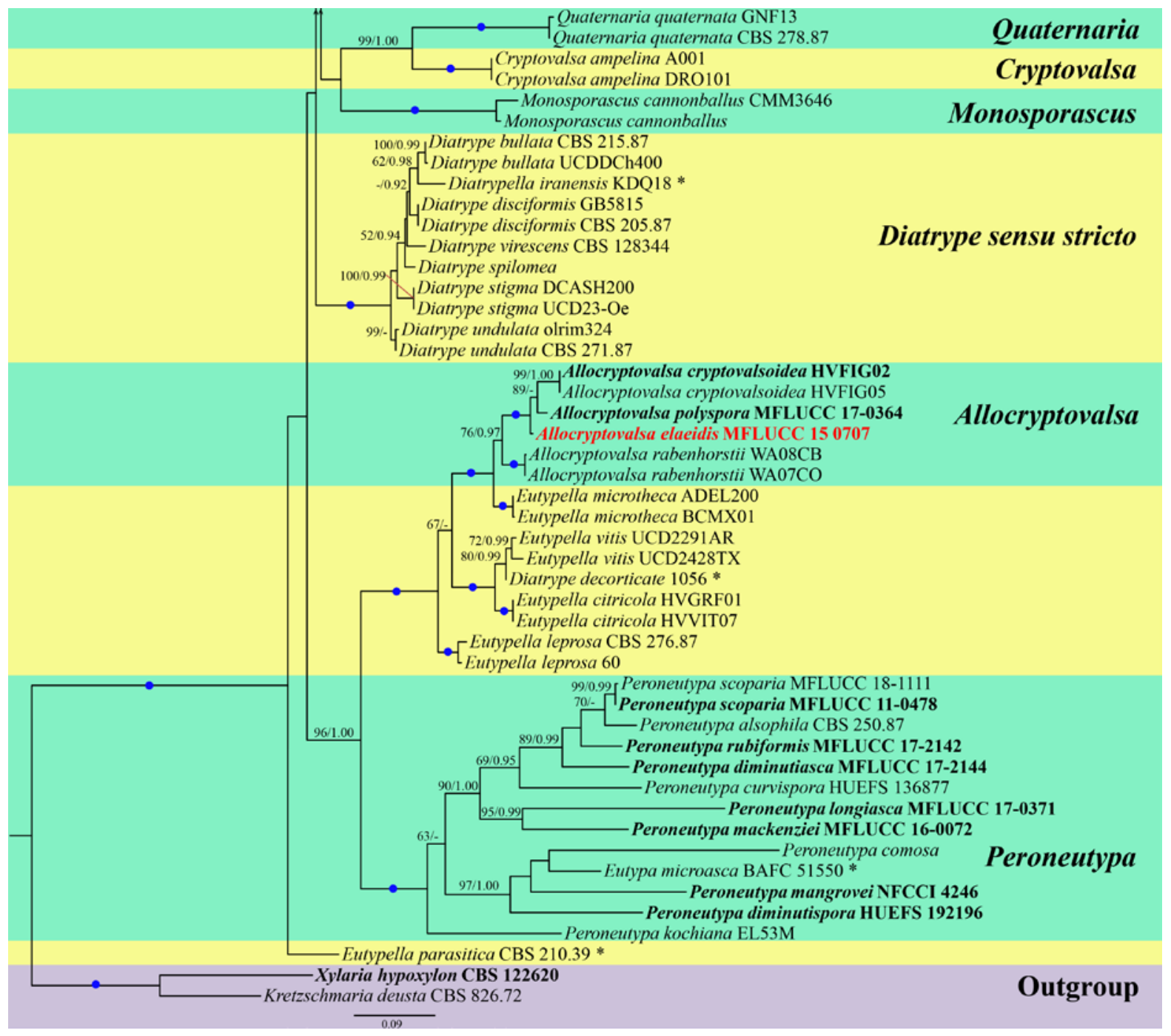

Figure 1 - Continued.

\section{Taxonomy}

Allocryptovalsa Senwanna, Phookamsak \& K.D. Hyde, in Senwanna, Phookamsak, Doilom, Hyde \& Cheewangkoon, Mycosphere 8(10): 1839 (2017)

Type species - Allocryptovalsa polyspora C. Senwanna, Phookamsak \& K.D. Hyde

Notes - Allocryptovalsa was introduced and is typified by A. polyspora Senwanna, Phookamsak \& K.D. Hyde, which was collected from Hevea brasiliensis (Senwanna et al. 2017). This genus comprises three species, A. cryptovalsoidea Trouillas, W.M. Pitt \& Gubler ex Senwanna, Phookamsak \& K.D. Hyde, A. polyspora and A. rabenhorstii (Nitschke) C. Senwanna, Phookamsak \& K.D. Hyde (Index Fungorum 2019).

Allocryptovalsa elaeidis Konta \& K.D. Hyde, sp. nov.

Index Fungorum number: IF556570, Facesoffungi number: FoF05116

Etymology - Epithet refers to host genus, Elaeis

Holotype - MFLU 15-1438 
Saprobic on dead petiole of Elaeis guineensis (Arecaceae). Sexual morph - Stromata (285)330-730(-950) $\mu \mathrm{m}$ long, (250-)350-890(-1030) $\mu \mathrm{m}$ wide $(\bar{x}=568 \times 600 \mu \mathrm{m}, \mathrm{n}=20)$, mostly solitary, sometimes gregarious, surrounded by black circle on host surface, immersed to erumpent in the bark, black, raised, pustulate, dome-shaped, 1-2-ascomata, with umbilicate ostiole appearing on the surface of stroma. Ascomata (including neck) 325-460 $\mu \mathrm{m}$ high, 315-515 $\mu \mathrm{m}$ diam. $(\bar{x}=365$ $\times 400 \mu \mathrm{m}, \mathrm{n}=20$ ), perithecial, immersed in the stroma, covered with the epidermis of plant tissue, delimited by a black zone in host tissues, globose to subglobose, glabrous, ostiole individual, with a short neck. Ostiolar canal 180-250 $\mu \mathrm{m}$ high, 160-230 $\mu \mathrm{m}$ diam. $(\bar{x}=250 \times 230 \mu \mathrm{m}, \mathrm{n}=5)$, sulcate, with periphyses. Peridium 25-86 $\mu \mathrm{m}$ wide $(\bar{x}=46 \mu \mathrm{m}, \mathrm{n}=30)$, composed of two sections, outer layer dark brown, thick-walled cells, arranged in textura angularis, inner layer hyaline, thin-walled cells of textura angularis. Hamathecium composed of $3-13 \mu \mathrm{m}$ wide $(\bar{x}=6 \mu \mathrm{m}, \mathrm{n}=40)$, filiform, septate, hyaline, unbranched, paraphyses. Asci (including stalks) (55-)68-147(-157) $\times 14-26 \mu \mathrm{m}$ $(\bar{x}=97 \times 18 \mu \mathrm{m}, \mathrm{n}=30)$, apex-bearing part (1.7-)2-4(-5.5) $\mu \mathrm{m}$ long $(\bar{x}=3 \mu \mathrm{m}, \mathrm{n}=30)$, polysporous, unitunicate, clavate, with moderately short stalks, stalk-bearing part 35-56 $\mu \mathrm{m}$ long $(\bar{x}$ $=50 \mu \mathrm{m}, \mathrm{n}=10)$. Ascospores (6-)7.5-9(-10.5) $\times 2-4 \mu \mathrm{m}(\bar{x}=9 \times 3 \mu \mathrm{m}, \mathrm{n}=100)$, overlapping, yellowish to brown, ellipsoidal to cylindrical or elongate-allantoid, aseptate, smooth-walled. Asexual morph - Undetermined.

Geographical distribution - Thailand.

Culture characters - Ascospores germinated on Malt Extract Agar (MEA) within 24 hours. Colonies on MEA, dense but thinner towards the edge, margin diffuse, white of upper surface (Fig. 2q).

Additional sequence data - LSU (MN308401), SSU (MN308419) (MFLUCC 15-0707).

Material examined - THAILAND, Krabi Province, on dead petiole of Elaeis guineensis Jacq. (Arecaceae), 3 December 2014, S. Konta, KBM01f (MFLU 15-1438, holotype); ex-type living culture = MFLUCC 15-0707.

Notes - Allocryptovalsa elaeidis is morphologically most similar to A. polyspora, overlapping in the number of ascomata per stroma, size of ascomata and asci (Senwanna et al. 2017). Although $A$. elaeidis and A. polyspora are morphologically similar, the phylogenetic analyses strongly support these collections as two distinct species. Allocryptovalsa elaeidis differs from A. cryptovalsoidea, A. polyspora, and A. rabenhorstii in host association, that is Elaeis guineensis (A. elaeidis), Ficus carica (A. cryptovalsoidea), Hevea brasiliensis (A. polyspora), Robinia L. and Vitis vinifera (A. rabenhorstii), respectively (Saccardo 1882, Trouillas et al. 2011, Senwanna et al. 2017). The species of this genus have been reported from Australia, Germany, Thailand, and USA (Saccardo 1882, Trouillas et al. 2011, Senwanna et al. 2017). Comparisons of the nucleotide between Allocryptovalsa species are shown in Table 5. Thus, A. elaeidis is introduced as the fourth species in Allocryptovalsa based on its different morphology coupled with high support values from the phylogenetic analysis (100\% ML, 1.00 BYPP, Fig. 1).

Allodiatrype Konta \& K.D. Hyde, gen. nov.

Index Fungorum number: IF556641; Facesoffungi number: FoF06299

Etymology - In reference to the morphological resemblance to Diatrype

Saprobic on dead petiole of palm (Arecaceae), and on a dead stem of unidentified plants. Sexual morph: Stromata scattered or aggregated on the host, erumpent, arising through cracks in the bark, irregularly shaped or circular, orbicular, convex surface, 1-10-ascomata immersed in one stroma, with or without a black stromatic zone. Ostiole opening through host bark and appearing as black spots, surrounded with a ring-like, ostiolar opening, composed of an outer layer of dark brown, small, tightly packed, thin parenchymatous cells and an inner layer of yellowish, large, loosely packed, parenchymatous cells. Ascomata perithecial, immersed in stromatic tissue, aggregated, brown, globose to sub-globose, narrowing towards the apex and very narrow at the base of ostiolar canal, thin-walled, ostiolate; ostiolar canal, with periphyses, ostiolar opening covered with carbonaceous, black cells; periphyses hyaline, filamentous. Peridium comprising an outer layer of yellow-brown, thick-walled cells of textura angularis and a thin, inner stratum of 
yellow, thick-walled cells of textura angularis. Hamathecium composed of septate, hyaline paraphyses. Asci unitunicate, 8-spored, with long, narrow, thin-walled stalk, with cylindrical, thickwalled, swollen upper portion, apex flat, with J-, cylindrical, conspicuous apical ring. Ascospores seriate, hyaline becoming yellowish at maturity, allantoid, unicellular, thin-walled, with small fat globules at each end, smooth-walled. Asexual morph: Undetermined.
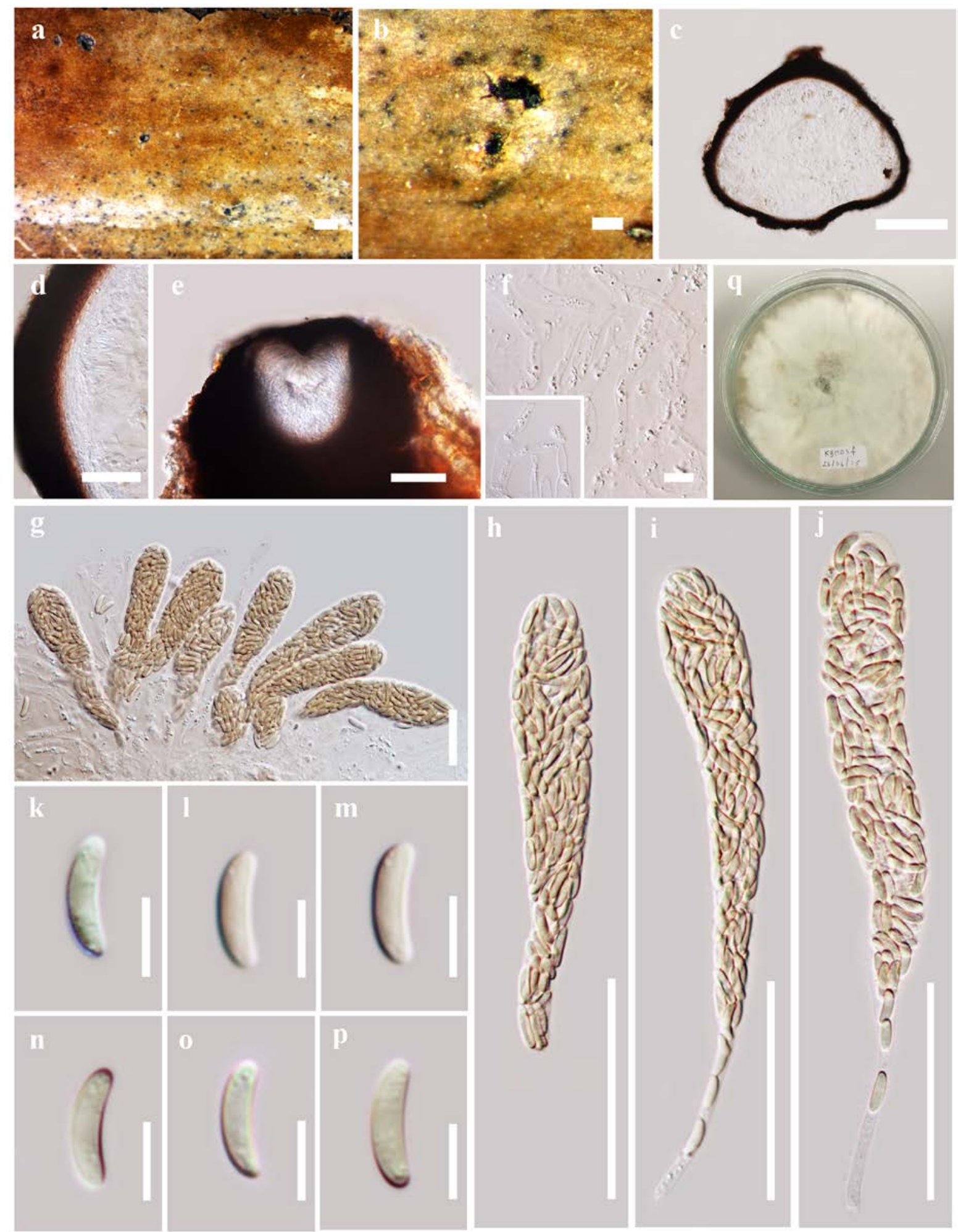

Figure 2 - Allocryptovalsa elaeidis (MFLU 15-1438, holotype) a Stromata on host substrate. b Close up of stroma. c Section of ascoma. d Peridium. e Ostiolar canal. f Paraphyses. g-j Asci. k-p Ascospores. q Colony on MEA. Bars: $\mathrm{a}=500 \mu \mathrm{m}, \mathrm{b}, \mathrm{c}=200 \mu \mathrm{m}, \mathrm{d}, \mathrm{e}=20 \mu \mathrm{m}, \mathrm{f}=10 \mu \mathrm{m}, \mathrm{g}-\mathrm{j}=50$ $\mu \mathrm{m}, \mathrm{k}-\mathrm{p}=5 \mu \mathrm{m}$. 
Geographical distribution - Thailand.

Type species - Allodiatrype arengae Konta \& K.D. Hyde

Notes - Allodiatrype is introduced to accommodate Allodiatrype arengae, A. elaeidicola, A. elaeidis, and A. (syn. Diatrype) thailandica. Allodiatrype is typified by A. arengae, which was collected from Arenga pinnata (Arecaceae). The morphology of Allodiatrype species is closely similar to that of Diatrype species. However, Allodiatrype differs in having 1-10-ascomata immersed in one stroma, and with or lacking a black stromatic zone, while stromata of Diatrype mostly spread over a large area, sometimes covering the host surface. As becomes evident from Fig. 1, strains of both genera appear in distinct clades in a phylogeny based on multiple strains of both genera, thereby justifying the erection of the new genus Allodiatrype.

Allodiatrype arengae Konta \& K.D. Hyde, sp. nov.

Fig. 3

Index Fungorum number: IF556929, Facesoffungi number: FoF05117

Etymology - Epithet refers to host genus, Arenga

Holotype - MFLU 15-1444

Saprobic on petiole of Arenga pinnata (Arecaceae). Sexual morph: Stromata 690-940 $\mu \mathrm{m}$ long, 370-935 $\mu \mathrm{m}$ wide $(\bar{x}=830 \times 700 \mu \mathrm{m}, \mathrm{n}=10)$, with well-developed interior, solitary, superficial, black, without black stromatic, glabrous, subglobose to irregular, pustulate, 1-5ascomata, with umbilicate ostioles appearing on the surface of the stroma. Ostiole opening through host bark and appearing as black spots, surrounded with a ring-like structure, composed of an outer layer of dark brown, small, tightly packed, thin parenchymatous cells and an inner layer of yellow, large, loosely packed, parenchymatous cells. Ascomata (excluding necks) 250-400 $\mu \mathrm{m}$ high, 240$400 \mu \mathrm{m}$ diam. $(\bar{x}=340 \times 300 \mu \mathrm{m}, \mathrm{n}=25)$, perithecial, immersed in the stroma, globose to subglobose, glabrous, ostioles individual, with a short neck. Ostiolar canal 100-170 $\mu \mathrm{m}$ high, 70$130 \mu \mathrm{m}$ diam. $(\bar{x}=130 \times 100 \mu \mathrm{m}, \mathrm{n}=20)$, cylindrical, sulcate, with periphyses. Peridium 12-25 $\mu \mathrm{m}$ wide, $(\bar{x}=20 \mu \mathrm{m}, \mathrm{n}=40)$, composed of two sections, outer layer of brown to dark brown, thinwalled cells, arranged in textura angularis, inner layer of hyaline thin-walled cells of textura angularis. Hamathecium composed of 3-7 $\mu \mathrm{m}$ wide $(\bar{x}=5 \mu \mathrm{m}, \mathrm{n}=40)$, septate, hyaline paraphyses. Asci (excluding stalks), spore-bearing part (14-)20(-45) $\times(4-) 6-10(-12) \mu \mathrm{m}(\bar{x}=30 \times$ $8 \mu \mathrm{m}, \mathrm{n}=80)$, apically rounded, with J-apical ring, apex-bearing part (1.5-)3-5(-7.5) $\mu \mathrm{m}$ long $(\bar{x}=$ $4 \mu \mathrm{m}, \mathrm{n}=40)$, 8-spored, unitunicate, clavate, with long stalks, (28-)34-89(-103) $\mu \mathrm{m}$ long $(\bar{x}=64$ $\mu \mathrm{m}, \mathrm{n}=60)$. Ascospores $(6-) 7-10(-12) \times 2-3 \mu \mathrm{m}(\bar{x}=10 \times 2 \mu \mathrm{m}, \mathrm{n}=120)$, overlapping, yellowish to light-brown, ellipsoidal to cylindrical or elongate-allantoid, aseptate, smooth-walled. Asexual morph: Undetermined.

Geographical distribution - Thailand.

Culture characters - Ascospores germinated on MEA within 24 hours. Colonies on MEA, white in beginning, dense but thinning towards the edge, margin diffuse, reverse pale yellow in the middle (Fig. 3q).

Additional sequence data - LSU (MN308402), SSU (MN308420), tef1 (MN525596), RPB2 (MN542886) (MFLUCC 15-0713).

Material examined - THAILAND, Phang-Nga Province, on dead petiole of Arenga pinnata (Wurmb) Merr. (Arecaceae), 4 December 2014, S. Konta, PHR01b (MFLU 15-1444, holotype); extype living culture $=$ MFLUCC 15-0713.

Notes - Allodiatrype arengae was collected from a dead petiole of Arenga pinnata from Phang-Nga Province, Thailand. Allodiatrype arengae is phylogenetically distinct from its sister species A. elaeidicola, A. elaeidis, and A. thailandica with high statistical support (100\% ML, 1.00 BYPP) (Fig. 1). A comparison of the nucleotide between Allodiatrype species and Diatrype disciformis is given in Table 6. Morphologically, A. arengae has superficial stromata lacking a black stromatic zone (Fig. 3a), while A. elaeidicola and A. elaeidis formed erumpent stromata, arising through the cracks in bark or epidermis with a black stromatic zone (Figs 4a, b, 5a), sometimes it covers the host surface (Fig. 4a, b). Other characters such as ascomata, asci and 
ascospores are mostly similar to A. thailandica, and their sizes also overlap. Our new strain is also recorded on a different host substrate from other species.

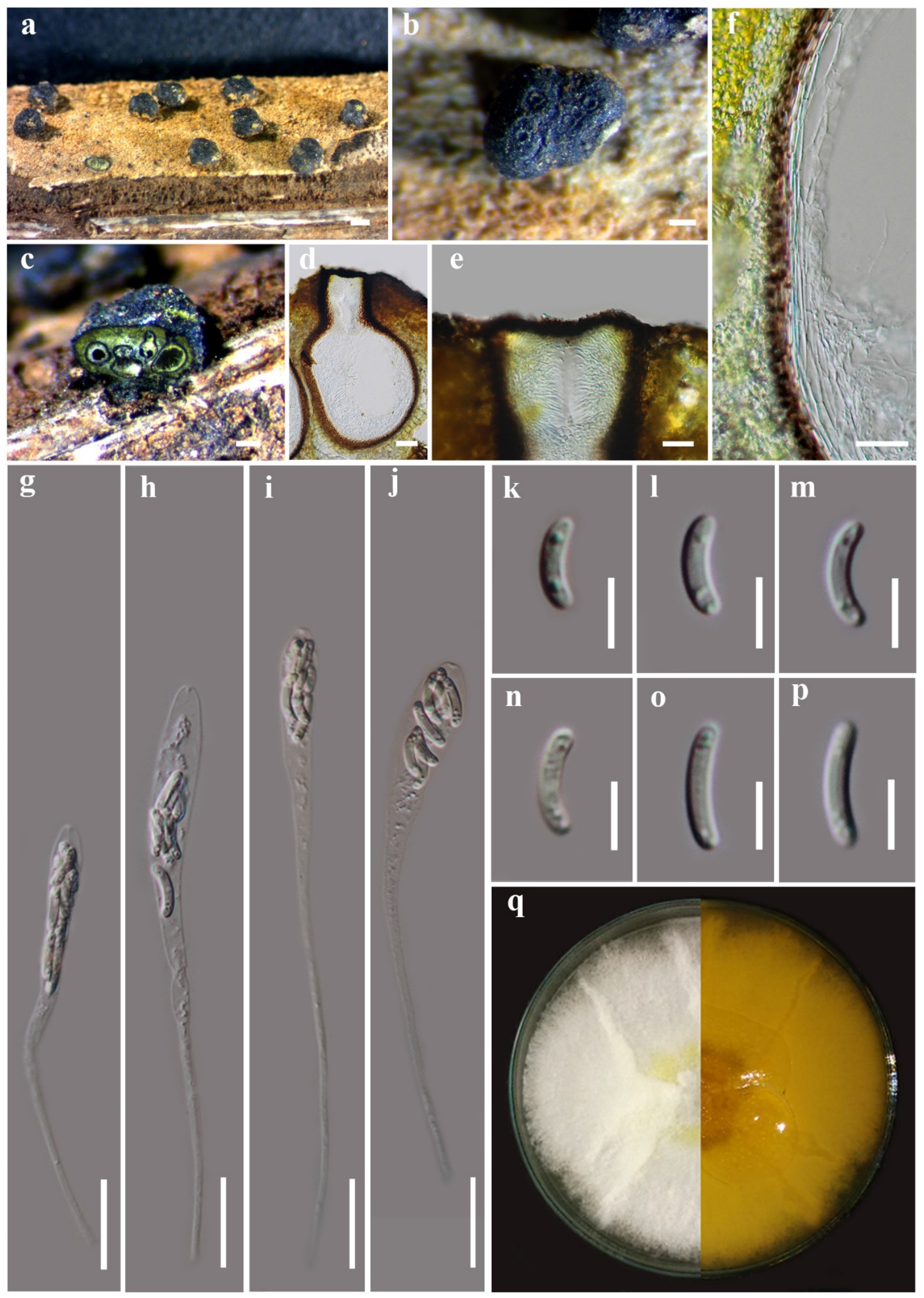

Figure 3 - Allodiatrype arengae (MFLU 15-1444, holotype) a Stromata on host substrate. b Close up of stroma (ostiole opening surrounded with a ring-like structure). c, d Section of stroma. e Ostiolar canal. f Peridium. g-j Asci. k-p Ascospores. q Colony on MEA. Bars: $\mathrm{a}=500 \mu \mathrm{m}, \mathrm{b}, \mathrm{c}=$ $200 \mu \mathrm{m}, \mathrm{d}, \mathrm{g}-\mathrm{j}=50 \mu \mathrm{m}, \mathrm{e}, \mathrm{f}=20 \mu \mathrm{m}, \mathrm{k}-\mathrm{p}=5 \mu \mathrm{m}$. 
Allodiatrype elaeidicola Konta \& K.D. Hyde, sp. nov.

Index Fungorum number: IF556930, Facesoffungi number: FoF05118

Etymology - Epithet refers to host genus, Elaeis

Holotype - MFLU 15-1468

Saprobic on petiole of Elaeis guineensis (Arecaceae). Sexual morph: Stromata 1.2-2.8 mm long, $0.96-1.66 \mathrm{~mm}$ diam. ( $\bar{x}=1.86 \times 1.19 \mathrm{~mm}, \mathrm{n}=15)$, with well-developed interior, solitary to gregarious, erumpent, black, with black stromatic zone extending down to the host surface, glabrous, irregular in shape, pustulate, multi-ascomata, with umbilicate ostioles appearing on the surface of the stroma. Ostiole opening through host bark and appearing as black spots, surrounded with a ring-like structure, composed of an outer layer of dark brown, small, tightly packed, thin parenchymatous cells and an inner layer of yellowish to orange, large, loosely packed, parenchymatous cells. Ascomata (excluding necks) 280-430 $\mu \mathrm{m}$ high, $180-435 \mu \mathrm{m}$ diam. $(\bar{x}=370$ $\times 270 \mu \mathrm{m}, \mathrm{n}=30$ ), perithecial, immersed in the stroma, globose to subglobose, glabrous, ostioles individual, with a short neck. Ostiolar canal 120-185 $\mu \mathrm{m}$ high, $60-120 \mu \mathrm{m}$ diam. $(\bar{x}=140 \times 95$ $\mu \mathrm{m}, \mathrm{n}=30)$, cylindrical, sulcate, with periphyses. Peridium $14-40 \mu \mathrm{m}$ wide $(\bar{x}=29 \mu \mathrm{m}, \mathrm{n}=30)$, composed of two section layers, outer part; brown to dark brown, thick-walled cells, arranged in textura angularis, inner layer; hyaline, thick-walled cells of textura angularis. Hamathecium undermined. Asci (excluding stalks), spore-bearing part (17-)20-31(-43) $\times 4-7 \mu \mathrm{m}(\bar{x}=26 \times 6 \mu \mathrm{m}$, $\mathrm{n}=50)$, apically rounded, with J-apical ring, apex-bearing part $(1.6-) 2-3(-5) \mu \mathrm{m}$ long $(\bar{x}=3, \mathrm{n}=$ 20), 8-spored, unitunicate, clavate, with long stalks, stalk-bearing part (32-)40-60(-76) $\mu \mathrm{m}$ long $(\bar{x}$ $=50 \mu \mathrm{m}, \mathrm{n}=20)$. Ascospores (6.5-)8-10(-11) $\times 1.5-3 \mu \mathrm{m}(\bar{x}=9 \times 2 \mu \mathrm{m}, \mathrm{n}=100)$, overlapping, yellowish to brown, ellipsoidal to cylindrical or elongate-allantoid, aseptate, smooth-walled. Asexual morph: Undetermined.

Geographical distribution - Thailand.

Culture characters - Ascospores germinated on MEA within 24 hours and germ tube was produced from end cell. Colonies on MEA, white when beginning, dense but thinner towards edge, margin diffuse, reverse coloration yellow (Fig. 4r).

Additional sequence data - LSU (MN308406), SSU (MN308424), tef1 (MN525598), RPB2 (MN542889) (MFLUCC 15-0737a); LSU (MN308407), SSU (MN308425), RPB2 (MN542890) (MFLUCC 15-0737b).

Material examined - THAILAND, Phang-Nga Province, on dead petiole of Elaeis guineensis Jacq. (Arecaceae), 5 December 2014, S. Konta, PHR10f (MFLU 15-1468, holotype, HKAS95035, Fig. 4); ex-type living culture = MFLUCC 15-0737.

Notes - In the phylogenetic analyses, Allodiatrype elaeidicola is related to A. elaeidis and A. thailandica with low bootstrap support (Fig. 1). However, the taxon is different in having yellow to dark orange inner cells in the stromata (Fig. 4c, d) and thinner walled asci (Fig. 4i), while other species have white to yellow inner cells in the stromata. A comparison of SSU, ITS, TUB2, RBP2 nucleotides to the type species, $A$. arengae shows that $A$. elaeidicola is significantly different from A. arengae (SSU, 1/1030 bp (0.09\%); ITS, 13/605 bp (2.14\%); TUB2, 28/1586 bp (1.76\%); RBP2, 3/1139 bp (0.26\%) (Table 6).

Allodiatrype elaeidis Konta \& K.D. Hyde, sp. nov.

Fig. 5

Index Fungorum number: IF556931, Facesoffungi number: FoF05119

Etymology - Epithet refers to host genus, Elaeis

Holotype - MFLU 15-1439

Saprobic on petiole of Elaeis guineensis (Arecaceae). Sexual morph - Stromata $470-860 \mu \mathrm{m}$ long, 440-710 $\mu \mathrm{m}$ diam. $(\bar{x}=630 \times 550 \mu \mathrm{m}, \mathrm{n}=10)$, with well-developed interior, solitary to gregarious, erumpent, black, with black stromatic zone on host surface, glabrous, irregular in shape, pustulate, bi- to multi-ascomata, with umbilicate ostioles appearing on the surface of the stroma. Ostiole opening through host bark and appearing as black spots, surrounded with a ring-like structure, composed of an outer layer of dark brown, small, tightly packed, thin parenchymatous cells and an inner layer of white to light-yellow, large, loosely packed, parenchymatous cells. 


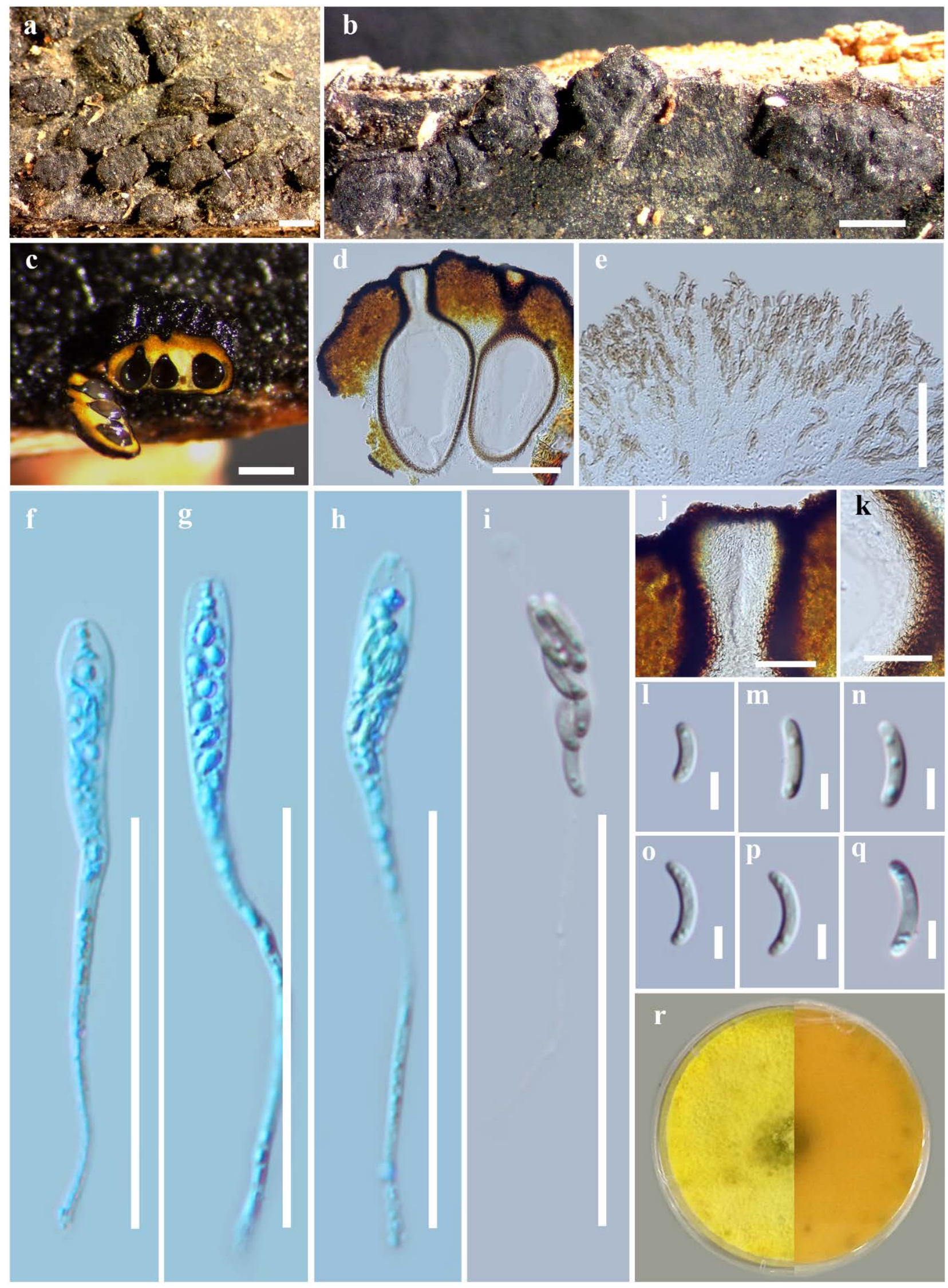

Figure 4 - Allodiatrype elaeidicola (MFLU 15-1468, holotype) a Stromata on host substrate. b Close up of stromata (ostiole opening surrounded with a ring-like structure). c, d Section of stroma. e, i Mature asci. $\mathrm{f}-\mathrm{h}$ Immature asci stained in cotton blue. j Ostiolar canal. k Peridium. l-q Ascospores. $\mathrm{r}$ Colony on MEA. Bars: $\mathrm{a}, \mathrm{b}=1000 \mu \mathrm{m}, \mathrm{c}=500 \mu \mathrm{m}, \mathrm{d}=200 \mu \mathrm{m}, \mathrm{e}-\mathrm{k}=50 \mu \mathrm{m}, \mathrm{l}-\mathrm{q}=$ $5 \mu \mathrm{m}$. 
Ascomata (excluding necks) 250-350 $\mu \mathrm{m}$ high, $230-300 \mu \mathrm{m}$ diam. $(\bar{x}=330 \times 280 \mu \mathrm{m}, \mathrm{n}=10)$, perithecial, immersed in the stroma, globose to subglobose, glabrous, ostioles individual, with a short neck. Ostiolar canal 100-130 $\mu \mathrm{m}$ high, 95-115 $\mu \mathrm{m}$ diam. $(\bar{x}=120 \times 110 \mu \mathrm{m}, \mathrm{n}=10)$, cylindrical, sulcate, with periphyses. Peridium 20-40 $\mu \mathrm{m}$ wide $(\bar{x}=30 \mu \mathrm{m}, \mathrm{n}=50)$, composed of two section layers, outer part; brown to dark brown, thick-walled cells, arranged in textura angularis, inner layer; hyaline, thick-walled cells of textura angularis. Hamathecium composed of 2-7 $\mu \mathrm{m}$ wide $(\bar{x}=4 \mu \mathrm{m}, \mathrm{n}=60)$, filiform, longer than asci, septate, branch, hyaline, paraphyses. Asci (excluding stalks), spore-bearing part (17-)20-30(-39) $\times 9-11(-14) \mu \mathrm{m}(\bar{x}=25 \times 11 \mu \mathrm{m}, \mathrm{n}=$ $60)$, apically rounded, with J- apical ring, apex-bearing part (1.5-)2-3(-5) $\mu \mathrm{m}$ long $(\bar{x}=3 \mu \mathrm{m}, \mathrm{n}=$ 60), 8-spores, unitunicate, clavate, with moderately long stalks, stalk-bearing part (28-)36-65(-94) $\mu \mathrm{m}$ long $(\bar{x}=50 \mu \mathrm{m}, \mathrm{n}=60)$. Ascospores $(6-) 8-10(-11) \times 1.5-3) \mu \mathrm{m}(\bar{x}=9 \times 2 \mu \mathrm{m}, \mathrm{n}=120)$, overlapping, yellowish to pale-brown, ellipsoidal to cylindrical or elongate-allantoid, aseptate, smooth-walled. Asexual morph - Undetermined.

Geographical distribution - Thailand.

Culture characters - Ascospores germinated on MEA within 24 hours and germ tube was produced from end cell. Colonies on MEA, white at beginning, thinner towards edge, margin diffuse, reverse coloration pale yellow (Fig. 5n).

Additional sequence data - LSU (MN308403), SSU (MN308421), tef1 (MN525597), RPB2 (MN542887) (MFLUCC 15-0708a); LSU (MN308404), SSU (MN308422), RPB2 (MN542888) (MFLUCC 15-0708b).

Material examined - THAILAND, Krabi Province, on dead petiole of Elaeis guineensis Jacq. (Arecaceae), 3 December 2014, S. Konta, KBM01g (MFLU 15-1439, holotype, Fig. 5); ex-type living culture $=$ MFLUCC 15-0708a.

Notes - Multigene phylogenetic analyses (Fig. 1( show that A. elaeidis (MFLUCC 15-0708( forms a distinct lineage within the Allodiatype clade and is related to A. elaeidicola with $61 \% \mathrm{ML}$ bootstrap support. Allodiatrype elaeidis is morphologically similar to A. arengae, A. elaeidicola and A. thailandica in ascospore size. However, the species differs in its wider asci $(9-14 \mu \mathrm{m})$. A comparison of ITS, TUB2, RBP2 nucleotides with A. arengae shows that A. elaeidis is significantly different from A. arengae (ITS, 13/621 bp (2.09\%(; TUB2, 16/1579 bp (1.01\%); RBP2, 2/1138 bp (0.17\%) (Table 6).

Allodiatrype thailandica (R.H. Perera, Jian K. Liu \& K.D. Hyde) Konta \& K.D. Hyde, comb. nov. Index Fungorum number: IF556932, Facesoffungi number: FoF01797

三 Diatrype thailandica R.H. Perera, Jian K. Liu \& K.D. Hyde, Fungal Diversity 78: 1-237. 10.1007/s13225-016-0366-9, [105] (2016)

Description: For original description see Li et al. )2016(.

Additional sequence data - LSU (MN308405), SSU (MN308423) (MFLUCC 15-0711).

Material examined - THAILAND, Phang-Nga Province, on dead petiole of Calamus sp. (Arecaceae), 6 December 2014, S. Konta, DNH05f (MFLU 15-1442, Fig. 6); living culture = MFLUCC 15-0711.

Notes - According to our analysis in Fig. 1, Diatrype thailandica grouped together with Allodiatrype species without bootstrap support. This species only has LSU, ITS and SSU sequence data and multigene analysis of ITS and TUB2 sequence data could not be resolved it from the extype of A. elaeidicola. ITS is unlikely to provide good resolution in Diatrypaceae (Hongsanan et al. 2018). Thus, Diatrype thailandica is synonymized under Allodiatrype. Diatrype thailandica was collected on stems of an unidentified plant from Chiang Rai, Thailand ( $\mathrm{Li}$ et al. 2016) and in this study, we collected it from Calamus (Arecaceae) in Phang-Nga Province. Morphological characters obtained from the fresh specimen is similar to the description provided by Li et al. (2016). 


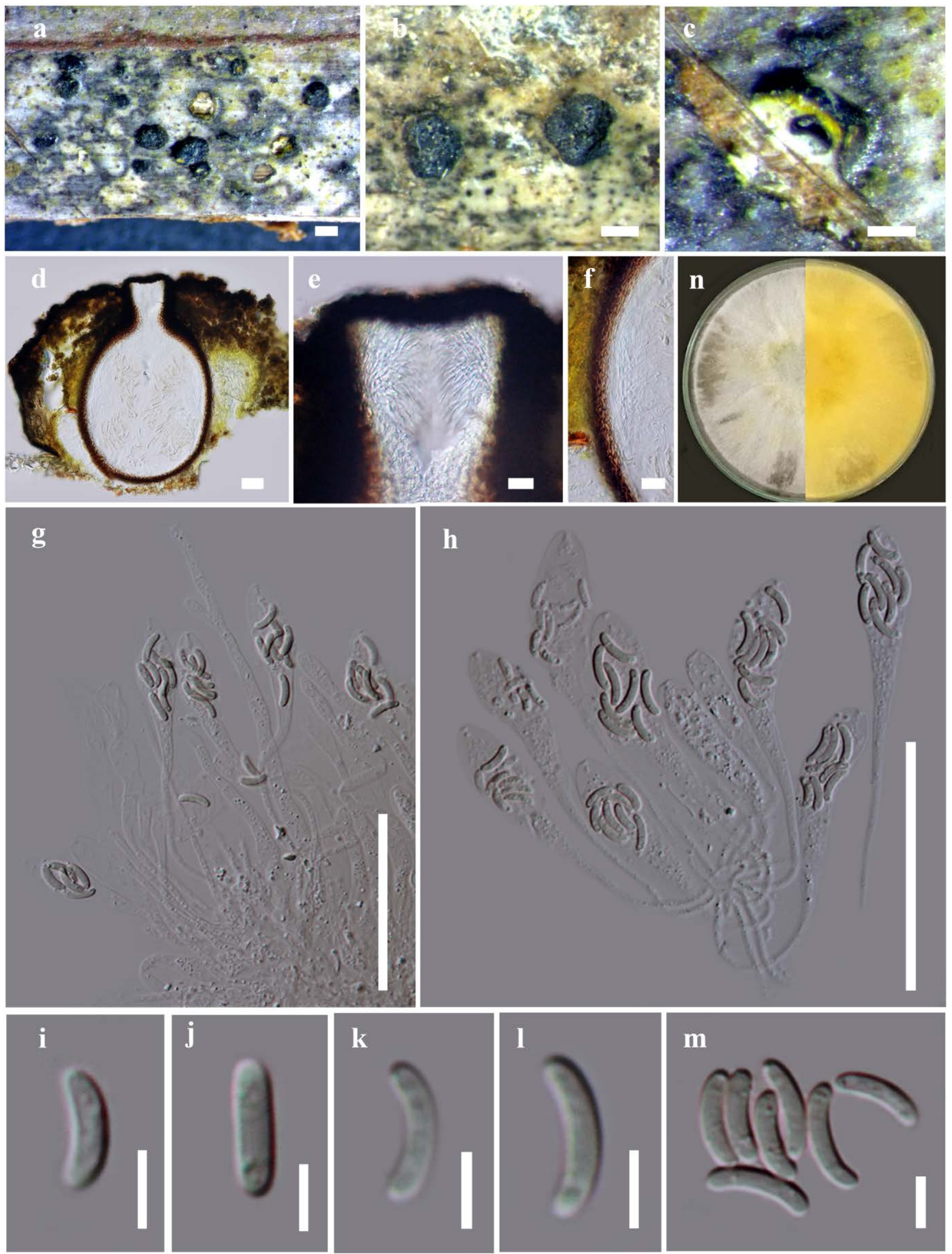

Figure 5 - Allodiatrype elaeidis (MFLU 15-1439, holotype) a Stromata on host substrate. b Close up of stromata (ostiole opening surrounded with a ring-like structure). c, d Section of stromata. e Ostiolar canal. f Peridium. g, h Asci. i-m Ascospores. $\mathrm{n}$ Colony on MEA. Bars: a, b $=500 \mu \mathrm{m}, \mathrm{c}=$ $200 \mu \mathrm{m}, \mathrm{d}, \mathrm{g}, \mathrm{h}=50 \mu \mathrm{m}, \mathrm{e}, \mathrm{f}=20 \mu \mathrm{m}, \mathrm{i}-\mathrm{m}=5 \mu \mathrm{m}$. 

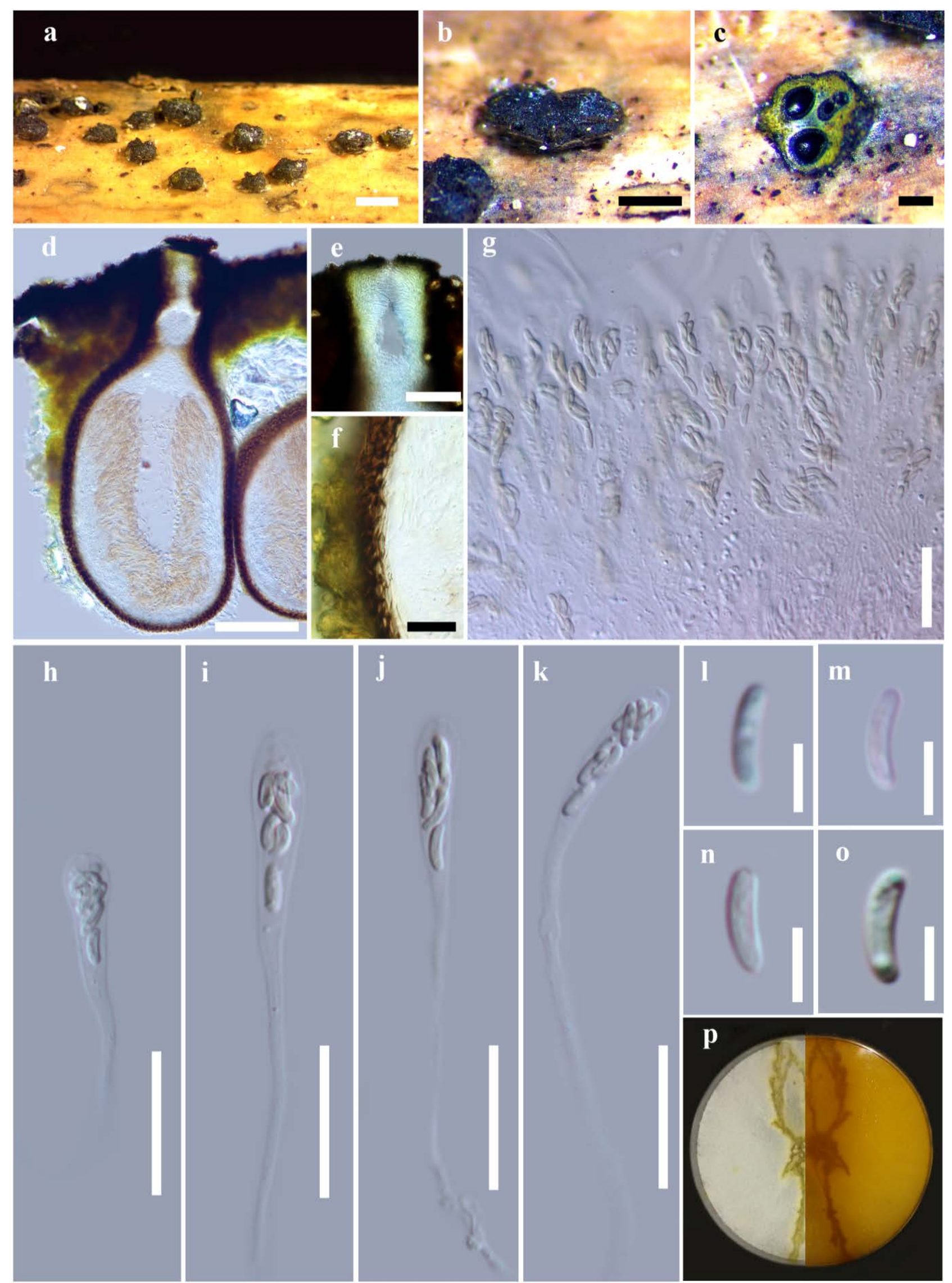

Figure 6 - Allodiatrype thailandica (MFLU 15-1442) a Stromata on host substrate. b Close up of stromata. c, d Section of stroma. e Ostiolar canal. f Peridium. g-k Asci. l-o Ascospores. q Colony on MEA. Bars: $\mathrm{a}=1000 \mu \mathrm{m}, \mathrm{b}=500 \mu \mathrm{m}, \mathrm{c}=200 \mu \mathrm{m}, \mathrm{e}=50 \mu \mathrm{m}, \mathrm{f}, \mathrm{h}-\mathrm{k}=20 \mu \mathrm{m}, \mathrm{l}-\mathrm{o}=5 \mu \mathrm{m}$. 
Diatrypella (Ces. \& De Not.) De Not

Type species - Diatrypella verruciformis (Ehrh.) Nitschke

= Diatrypella favacea (Fr.) Ces. \& De Not., Sfer. Ital.: 29 (1863))

Notes - The polyphyletic nature of Diatrypella has been reported based on the phylogeny of ITS and TUB2 genes (de Almeida et al. 2016, Mehrabi et al. 2016, Senwanna et al. 2017, Shang et al. 2017, Hyde et al. 2019). Currently, 114 epithets are listed under Diatrypella (Index Fungorum 2019). Recently an additional species, Diatrypella delonicis R.H. Perera \& K.D. Hyde. was introduced by Hyde et al. (2019).

Diatrypella heveae Senwanna, Phookamsak \& K.D. Hyde, in Senwanna, Phookamsak, Doilom, Hyde \& Cheewangkoon, Mycosphere 8(10): 1846 (2017)

Index Fungorum number: IF553859, Facesoffungi number: FoF05121

Fig. 7

Saprobic on petiole of Brahea armata (Arecaceae). Sexual morph: Stromata 660-2155 $\mu \mathrm{m}$ long, $285-860 \mu \mathrm{m}$ wide $(\bar{x}=1430 \times 500 \mu \mathrm{m}, \mathrm{n}=11)$, with well-developed interior, solitary to gregarious, erumpent in the bark, black, fusiform in shape, pustulate, 1-2-ascomata. Ascomata (excluding necks) 70-300 $\mu \mathrm{m}$ high, 90-260 $\mu \mathrm{m}$ diam. $(\bar{x}=181 \times 210 \mu \mathrm{m}, \mathrm{n}=20)$, immersed in the stroma, sub globose to irregular, ostioles individual, with a short neck. Ostiolar canal 110-180 $\mu \mathrm{m}$ high, $80-140 \mu \mathrm{m}$ diam. $(\bar{x}=140 \times 110 \mu \mathrm{m}, \mathrm{n}=20)$, cylindrical, sulcate, with periphyses. Peridium 10-35 $\mu \mathrm{m}$ wide $(\bar{x}=22 \mu \mathrm{m}, \mathrm{n}=30)$, composed of two layers, outer layer of brown, thin-walled cells, arranged in textura angularis, inner layer of hyaline, thick-walled cells of textura angularis. Hamathecium composed of $2-5 \mu \mathrm{m}$ wide $(\bar{x}=3 \mu \mathrm{m}, \mathrm{n}=30)$, filiform, longer than asci, septate, hyaline paraphyses. Asci (including stalks), spore-bearing part (55-)64-90(-105) $\times(12-) 13-$ $16(-18) \mu \mathrm{m}(\bar{x}=80 \times 15 \mu \mathrm{m}, \mathrm{n}=50)$, apically rounded, with J- apical ring, apex-bearing part 24(-6) $\mu \mathrm{m}$ long $(\bar{x}=3, \mathrm{n}=35)$, polysporous, unitunicate, clavate, with moderately short stalks, stalkbearing part 24-36 $\mu \mathrm{m}$ long $(\bar{x}=35 \mu \mathrm{m}, \mathrm{n}=20)$. Ascospores $(5-) 6-10(-13) \times 1-2.5 \mu \mathrm{m}(\bar{x}=7 \times 2$ $\mu \mathrm{m}, \mathrm{n}=130$ ), overlapping, yellowish to brown, ellipsoidal to cylindrical or elongate-allantoid, aseptate, smooth-walled. Asexual morph: Undetermined.

Geographical distribution - Thailand, Chiang Rai, Wiang Chiang Rung District (Senwanna et al. 2017).

Culture characters - Ascospores germinated on MEA within 24 hours, germ tube produced from end cell. Colonies on MEA smooth, white, dense towards the edge, margin diffuse (Fig. 7v).

Additional sequence data - LSU (MN308409), SSU (MN308427), tef1 (MN525600), RPB2 (MN542892) (MFLUCC 15-0274).

Material examined - THAILAND, Chiang Rai Province, Mae Chan District, on dead petiole of Brahea armata S. Watson. (Arecaceae), 25 November 2014, S. Konta, HR01a (MFLU 15-0020); living culture = MFLUCC 15-0274.

Notes - We collected and illustrated Diatrypella heveae (MFLU 15-0020) from Chiang Rai Province, Thailand associated with Brahea armata (Arecaceae). This is the second record of this species and the first record of $D$. heveae on a palm; the holotype was collected on rubber from the same province (Senwanna et al. 2017). The phylogenetic results suggested that our strain is the same species, $D$. heveae. The morphological characteristics largely resemble those of $D$. heveae (e.g., the measurements of ascomata, ostiolar canals, peridia, asci, and ascospores, revealed overlapping sizes). However, MFLU 15-0020 differs in having fusiform stromata while the type specimen of $D$. heveae has rounded to irregular stromata and fewer ascomata within a stroma (1-2 versus 4-5) (Senwanna et al. 2017). The sequence data of LSU, SSU, ITS, tef1, RPB2, and TUB2 are almost identical to those of the ex-type.

Diatrypella elaeidis Konta \& K.D. Hyde, sp. nov.

Fig. 8

Index Fungorum number: IF556572, Facesoffungi number: FoF05122

Etymology - Refers to host genus, Elaeis

Holotype - MFLU 15-0025 


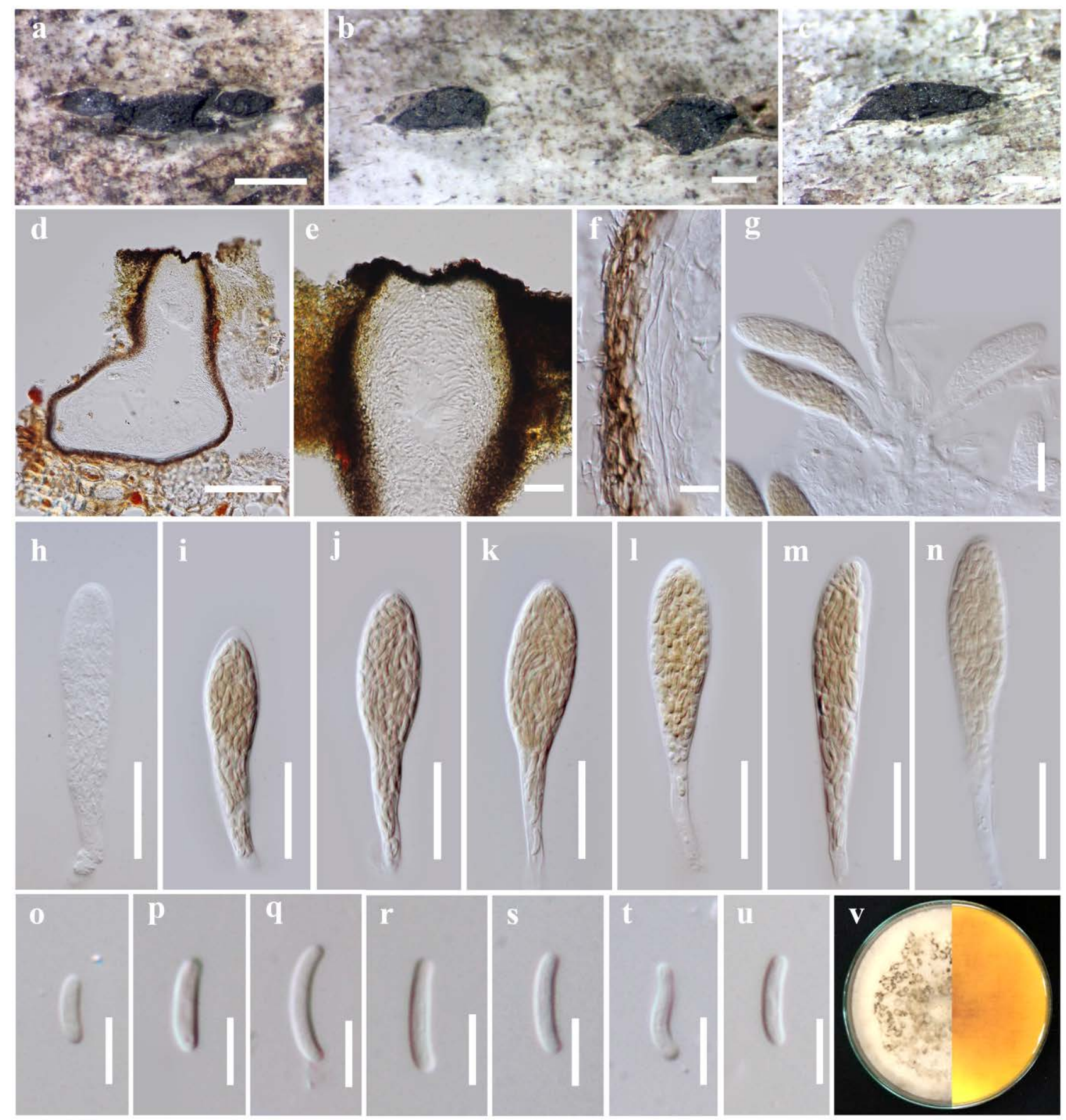

Figure 7 - Diatrypella heveae (MFLU 15-0020) a Stromata on host substrate. b, c Close up of stromata. d Section of stroma. e Ostiolar canal. f Peridium. g-n Asci. o-u Ascospores. v Colony on MEA. Bars: $\mathrm{a}=1000 \mu \mathrm{m}, \mathrm{b}, \mathrm{c}=500 \mu \mathrm{m}, \mathrm{d}=50 \mu \mathrm{m}, \mathrm{e}, \mathrm{f}, \mathrm{g}-\mathrm{n}=20 \mu \mathrm{m}, \mathrm{o}-\mathrm{u}=5 \mu \mathrm{m}$.

Saprobic on petiole of Elaeis guineensis (Arecaceae). Sexual morph: Stromata 1025-3965 $\mu \mathrm{m}$ long, $285-860 \mu \mathrm{m}$ wide $(\bar{x}=1950 \times 620 \mu \mathrm{m}, \mathrm{n}=35)$, with well-developed interior, solitary to gregarious, erumpent, black, glabrous, fusiform or lenticular in shape, pustulate, 1-2-ascomata. Ascomata 242-600 $\mu \mathrm{m}$ high, 240-424 $\mu \mathrm{m}$ diam. $(\bar{x}=350 \times 335 \mu \mathrm{m}, \mathrm{n}=25)$, perithecial, immersed in the stroma, globose to subglobose, ostioles individual, with a short neck. Ostiolar canal 100-200 $\mu \mathrm{m}$ high, $70-190 \mu \mathrm{m}$ diam. $(\bar{x}=140 \times 120 \mu \mathrm{m}, \mathrm{n}=20)$, cylindrical, sulcate, with periphyses. Peridium 22-55 $\mu \mathrm{m}$ wide $(\bar{x}=33 \mu \mathrm{m}, \mathrm{n}=45)$, composed of two layers, outer part of brown, thickwalled cells, arranged in textura angularis, inner layers of hyaline, thick-walled cells of textura angularis. Hamathecium composed of $2-8 \mu \mathrm{m}$ wide $(\bar{x}=4 \mu \mathrm{m}, \mathrm{n}=70)$, filiform, longer than asci, septate, hyaline paraphyses. Asci (excluding stalks), spore-bearing part (29-)40-70(-98) × (7-)11- 
$15(-17) \mu \mathrm{m}(\bar{x}=60 \times 12 \mu \mathrm{m}, \mathrm{n}=70)$, apically rounded, with J-apical ring, apex-bearing part (0.5)1-3(-5) $\mu \mathrm{m}$ long $(\bar{x}=2 \mu \mathrm{m}, \mathrm{n}=35)$, polysporous, unitunicate, cylindrical, with moderately short stalks, stalk-bearing part (18-)25-40(-57) $\mu \mathrm{m}$ long $(\bar{x}=33 \mu \mathrm{m}, \mathrm{n}=20)$. Ascospores $(3.5-) 5-7(-10)$ $\times 1.5-3 \mu \mathrm{m}(\bar{x}=6 \times 2 \mu \mathrm{m}, \mathrm{n}=130)$, overlapping, yellowish to brown, ellipsoidal to cylindrical or elongate-allantoid, aseptate, smooth-walled. Asexual morph: Undetermined.

Geographical distribution - Thailand.

Culture characters - Ascospores germinated on MEA within 24 hours. Colonies on MEA smooth, white, dense towards the edge, margin diffuse (Fig. 8r).

Additional sequence data - LSU (MN308408), SSU (MN308426), tef1 (MN525599), RPB2 (MN542891) (MFLUCC 15-0279).

Material examined - THAILAND, Chiang Rai Province, Mae Chan District, on dead petiole of Elaeis guineensis Jacq. (Arecaceae), 25 November 2014, S. Konta, HR03a (MFLU 15-0025, holotype); ex-type living culture = MFLUCC 15-0279.

Notes - Diatrypella elaeidis clearly differs from other species in the genus by its fusiform stroma with 1-2-ascomata immersed in the stroma and their dimensions. Diatrypella elaeidis forms a sister clade to $D$. delodicis with bootstrap support of 68\% ML, 0.90 BYPP (Fig. 1). However, $D$. elaeidis is distinguished from $D$. delodicis in having black long fusiform stroma, while, $D$. delodicis has pale to dark brown globose to subglobose stroma with a flattened base. Additionally, the number of perithecia per stroma, $D$. elaeidis is less than those in $D$. delodicis (1-2 vs 3-4), asci and hamathecium of $D$. elaeidis are smaller than those of $D$. delodicis (asci; $61 \times 12 \mu \mathrm{m}$ vs $100 \times$ $18 \mu \mathrm{m}$, hamathecium $4 \mu \mathrm{m}$ vs $9.8 \mu \mathrm{m}$ wide) (Hyde et al. 2019). Diatrypella delodicis was found in Chiang Rai on dried seed pods of Delonix regia (Fabaceae) (Hyde et al. 2019), while D. elaeidis was collected from Elaeis guineensis. A comparison of the nucleotide of D. elaeidis to D. delodicis, $D$. heveae, and $D$. verruciformis (type species) is given in Table 7.

\section{Discussion}

Diatrypaceae species are difficult to identify based on morphology due to overlapping phenotypic characters (Glawe \& Rogers 1984, Trouillas et al. 2011, Dayarathne et al. 2016, Senwanna et al. 2017, Shang et al. 2017). Many studies have revealed several new hosts of species and have contributed to our knowledge of their geographical distribution (Moyo et al. 2019). In this study, we introduce a new genus and five new species for family Diatrypaceae based on morphology combined with phylogeny. New hosts and new geographical distribution records are also provided. This supports the high novelty of fungal species in Thailand in this family (Hyde et al. 2018). The asexual morphs of Diatrypaceae are usually coelomycetes, but are not generally useful in separating species (Glawe \& Rogers 1982, 1984). Allocryptovalsa (Allocryptovalsa clade, Fig. 1) appears to be a monophyletic group in Diatrypaceae, as was established in previous phylogenetic studies (Senwanna et al. 2017, Hyde et al. 2019). Molecular data are available for $A$. cryptovalsoidea, A. polyspora and A. rabenhorstii (Trouillas et al. 2011, Senwanna et al. 2017).

In our phylogenetic analyses, a novel genus Allodiatrype is introduced. Three novel taxa and a novel combination grouped together but constitute separate lineages (Allodiatrype clade, Fig. 1). The strains of Diatrypella form a well-resolved clade (Fig. 1). However, in this clade, some strains of Diatrype (D. oregonensis, D. prominens) are placed between Diatrypella species. In same case, some strains of Diatrypella species such as D. banksiae, D. decorticata, D. favacea and D. iranensis often form distinct lineages within Diatrypaceae (Fig. 1). This may be due to lack of TUB2 gene sequences or misidentified species. Hence, fresh collections and sequence data are required to resolve their phylogenetic placement within the family.

Nine genera of Diatrypaceae out of 18 genera (Table 3) have been recorded from palms worldwide (Arecaceae). Of these, seven genera and 20 species (Table 4) have been recorded in Thailand. In addition, our taxa were isolated from dead parts of palms (Arecaceae). They were collected in the same period (November to December 2014) but from different habitats. However, our collection of diatrypaceous fungi are distributed in different hosts as well as different parts of the palms (Arecaceae) and different locations. Moyo et al. (2019) have discussed these aspects and 


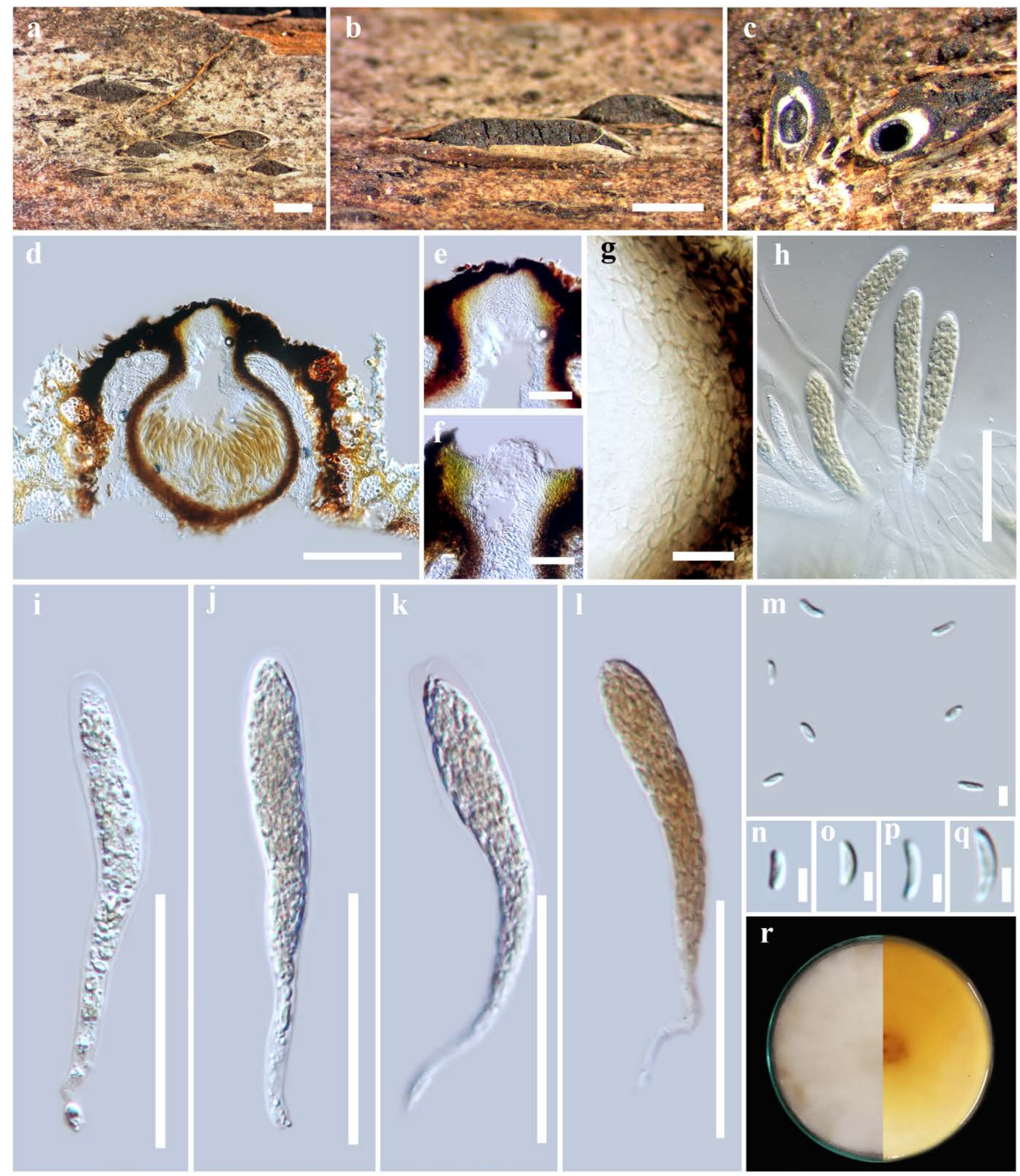

Figure 8 - Diatrypella elaeidis (MFLU 15-0025, holotype) a Stromata on host substrate. b Close up of stromata. c, d Sections of stromata. e, f Ostiolar canal. g Peridium. h-l Asci. m-q Ascospores. r Colony on MEA. Scale bars: $\mathrm{a}, \mathrm{b}=1000 \mu \mathrm{m}, \mathrm{c}=500 \mu \mathrm{m}, \mathrm{d}=200 \mu \mathrm{m}, \mathrm{e}, \mathrm{f}, \mathrm{h}-\mathrm{l}=50 \mu \mathrm{m}, \mathrm{g}=20$ $\mu \mathrm{m}, \mathrm{m}-\mathrm{q}=5 \mu \mathrm{m}$.

concluded that broad sampling across the globe might be required to fully comprehend the host associations and distribution of Diatrypaceae.

Our analysis (Fig. 1) showed that Peroneutypa forms a monophyletic clade with high statistical support (96\% ML, 1.00 BYPP). A putatively named strain, Eutypa microasca (BAFC 51550) is placed within this clade but without good statistical support, as shown in the original publication and other studies (Grassi et al. 2014, Shang et al. 2018, Hyde et al. 2019, Phookamsak et al. 2019). 
This is just one of many cases showing that the generic concepts of Diatrypaceae are in need of revision. In addition, many genera appear paraphyletic or even polyphyletic in our current phylogeny based on the available material. This situation can only be changed by substantial amounts of fieldwork aimed at collection and culturing of the "missing” taxa, along with careful morphological studies and multi-locus phylogenies.

Table 3 World distribution of Diatrypaceae on palms (Arecaceae).

\begin{tabular}{|c|c|c|c|c|}
\hline Genera & Species name & Hosts & Countries & References \\
\hline Allocryptovalsa & A. elaeidis Konta \& K.D. Hyde. & Elaeis guineensis & Thailand & This study \\
\hline \multirow[t]{4}{*}{ Allodiatrype } & A. arengae Konta \& K.D. Hyde. & Arenga pinnata & Thailand & This study \\
\hline & A. elaeidicola Konta \& K.D. Hyde. & Elaeis guineensis & Thailand & This study \\
\hline & A. elaeidis Konta \& K.D. Hyde. & Elaeis guineensis & Thailand & This study \\
\hline & $\begin{array}{l}\text { A. thailandica (R.H. Perera, Jian K. Liu \& K.D. Hyde) Konta \& } \\
\text { K.D. Hyde. } \\
\quad \equiv \text { Diatrype thailandica R.H. Perera, Jian K. Liu \& K.D. Hyde }\end{array}$ & Calamus sp. & Thailand & This study \\
\hline \multirow[t]{2}{*}{ Anthostoma } & A. cocois Höhn. & Cocos nucifera & Samoa & Dingley et al. (1981) \\
\hline & A. yatay Speg. & Cocos yatay & Argentina & Farr (1973) \\
\hline \multirow[t]{2}{*}{ Cryptovalsa } & $\begin{array}{l}\text { C. deusta (Ellis \& G. Martin) Petr. } \\
\equiv \text { Diatrypella deusta Ellis \& G. Martin. }\end{array}$ & Sabal serrulata & $\begin{array}{l}\text { China, U.S.A. } \\
\text { (Florida) }\end{array}$ & $\begin{array}{l}\text { Cash (1952), Petrak (1953), } \\
\text { Teng (1996) }\end{array}$ \\
\hline & $\begin{array}{l}\text { C. protracta (Pers.) De Not. } \\
\quad=\text { Diatrypella nitschkei (Fuckel) L.C. Tiffany \& J.C. Gilman. }\end{array}$ & Sabal palmetto & U.S.A. (Florida) & Petrak (1953) \\
\hline \multirow[t]{5}{*}{ Diatrype } & D. chlorosarca Berk. \& Broome. & $\begin{array}{l}\text { Archontophoenix alexandrae, } \\
\text { Archontophoenix sp., Trachycarpus } \\
\text { fortunei, Trachycarpus sp. }\end{array}$ & $\begin{array}{l}\text { China, Hong } \\
\text { Kong }\end{array}$ & $\begin{array}{l}\text { Lu et al. (2000), Zhuang } \\
\text { (2001), Taylor \& Hyde } \\
\text { (2003) }\end{array}$ \\
\hline & $\begin{array}{l}\text { D. euterpes (Henn.) Rappaz. } \\
\quad \equiv \text { Eutypa euterpes Henn. }\end{array}$ & Euterpe oleracea & Brazil & $\begin{array}{l}\text { Rappaz (1987), Mendes et } \\
\text { al. (1998) }\end{array}$ \\
\hline & D. palmarum Rick. & Phoenix sylvestris & India & Patil \& Patil (1983) \\
\hline & D. palmicola Jian K. Liu \& K.D. Hyde. & Caryota urens & Thailand & Liu et al. (2015) \\
\hline & Diatrype sp. & Rhopalostylis sp. & New Zealand & McKenzie et al. (2004) \\
\hline \multirow[t]{6}{*}{ Diatrypella } & D. heveae Senwanna, Phookamsak \& K.D. Hyde. & Brahea armata & Thailand & This study \\
\hline & D. borassi Chona \& Munjal. & $\begin{array}{l}\text { Trachycarpus fortunei, } \\
\text { Archontophoenix alexandrae, } \\
\text { Archontophoenix sp. }\end{array}$ & $\begin{array}{l}\text { Australia, Hong } \\
\text { Kong }\end{array}$ & $\begin{array}{l}\text { Lu et al. (2000), Zhuang } \\
\text { (2001), Taylor \& Hyde } \\
\text { (2003) }\end{array}$ \\
\hline & D. caryotae R.K. Verma. & Caryota urens & India & Verma (1996) \\
\hline & D. elaeidis Konta \& K.D. Hyde. & Elaeis guineensis & Thailand & This study \\
\hline & D. tuberculata Ellis \& Catkins ex Ellis \& Everh. & Sabal serrulata & U.S.A. (Florida) & Cash (1952) \\
\hline & Diatrypella sp. & Rhopalostylis sp. & New Zealand & McKenzie et al. (2004) \\
\hline Eutypa & E. rattanicola J. Fröhl. \& K.D. Hyde. & Calamus moti & Australia & Fröhlich \& Hyde (2000) \\
\hline Eutypella & E. arecae (Syd. \& P. Syd.) Rappaz. & $\begin{array}{l}\text { Areca catechu, Calamus tetradactylus, } \\
\text { Calamus sp., Trachycarpus fortunei }\end{array}$ & $\begin{array}{l}\text { China, Hong } \\
\text { Kong, }\end{array}$ & $\begin{array}{l}\text { Rappaz (1987), Fröhlich \& } \\
\text { Hyde (2000), Lu et al. (2000), }\end{array}$ \\
\hline
\end{tabular}


Table 3 Continued.

\begin{tabular}{|c|c|c|c|c|}
\hline Genera & Species name & Hosts & Countries & References \\
\hline & & & $\begin{array}{l}\text { Philippines, } \\
\text { Switzerland }\end{array}$ & $\begin{array}{l}\text { Zhuang (2001), Taylor \& } \\
\text { Hyde (2003) }\end{array}$ \\
\hline & E. rehmiana (Henn.) Höhn. & Areca catechu, Areca sp., Calamus sp. & Philippines & $\begin{array}{l}\text { Reinking }(1918,1919) \text {, } \\
\text { Teodoro }(1937)\end{array}$ \\
\hline & E. sabalina Cooke. & $\begin{array}{l}\text { Arecaceae, Chamaerops humilis, Sabal } \\
\text { minor, S. palmetto (三 Sabal } \\
\text { blackburniana), Sabal sp. }\end{array}$ & $\begin{array}{l}\text { Bermuda, China, } \\
\text { Georgia, U.S.A. } \\
\text { (Alabama, Florida, } \\
\text { Louisiana) }\end{array}$ & $\begin{array}{l}\text { Vizioli (1923), } \\
\text { Anonymous (1960), Tai } \\
\text { (1979), Alfieri et al. } \\
\text { (1984), Rappaz (1987), } \\
\text { Teng (1996), Glawe \& } \\
\text { Jones (1989), Zhuang } \\
\text { (2001) }\end{array}$ \\
\hline & Eutypella sp. & Rhopalostylis sp. & New Zealand & McKenzie et al. (2004) \\
\hline Peroneutypa & Peroneutypa sp. & Cocos nucifera & Cuba & Urtiaga (1986) \\
\hline
\end{tabular}

Table 4 Distribution of diatrypaceous fungi on plants in Thailand.

\begin{tabular}{|c|c|c|c|c|c|}
\hline Genera & Species name & Hosts & $\begin{array}{c}\text { Collection site } \\
\text { (Province) }\end{array}$ & Collection date & References \\
\hline \multirow[t]{2}{*}{ Allocryptovalsa } & A. polyspora Senwanna, Phookamsak \& K.D. Hyde. & Dead twig of Hevea brasiliensis & Phayao & 29 January 2017 & Senwanna et al. (2017) \\
\hline & A. elaeidis Konta \& K.D. Hyde. & Dead petiole of Elaeis guineensis & Krabi & 3 December 2014 & This study \\
\hline \multirow{5}{*}{ Allodiatrype } & A. arengae Konta \& K.D. Hyde. & Dead petiole of Arenga pinnata & Phang-Nga & 4 December 2014 & This study \\
\hline & A. elaeidicola Konta \& K.D. Hyde. & Dead petiole of Elaeis guineensis & Phang-Nga & 5 December 2014 & This study \\
\hline & A. elaeidis Konta \& K.D. Hyde. & Dead petiole of Elaeis guineensis & Krabi & 3 December 2014 & This study \\
\hline & $\begin{array}{l}\text { A. thailandica (R.H. Perera, Jian K. Liu \& K.D. Hyde) } \\
\text { Konta \& K.D. Hyde. }\end{array}$ & Dead petiole of Calamus sp. & Phang-Nga & 6 December 2014 & This study \\
\hline & $\begin{array}{l}\equiv \text { Diatrype thailandica R.H. Perera, Jian K. Liu \& } \\
\text { K.D. Hyde }\end{array}$ & Stems of unidentified plant & Chiang Rai & 12 March 2015 & Li et al. (2016) \\
\hline Diatrype & D. palmicola Jian K. Liu \& K.D. Hyde. & Dead branch of Caryota urens & Chiang Rai & 6 September 2010 & Liu et al. (2015) \\
\hline \multirow[t]{6}{*}{ Diatrypella } & D. tectonae M. Doilom, Q.J. Shang \& K.D. Hyde. & Dead branch of Tectona grandis & Chiang Rai & 5 February 2012 & Shang et al. (2017) \\
\hline & D. heveae Senwanna, Phookamsak \& K.D. Hyde. & Dead twig of Hevea brasiliensis & Chiang Rai & 1 November 2016 & Senwanna et al. (2017) \\
\hline & & Dead petiole of Brahea armata & Chiang Rai & 25 November 2014 & This study \\
\hline & D. vulgaris Trouillas, W.M. Pitt \& Gubler. & Stems of unidentified plant & Chiang Rai & 1 January 2015 & Hyde et al. (2017) \\
\hline & D. delonicis R.H. Perera \& K.D. Hyde. & Dried seed pods of Delonix regia & Chiang Rai & 10 December 2014 & Hyde et al. (2019) \\
\hline & D. elaeidis Konta \& K.D. Hyde. & Dead petiole of Elaeis guineensis & Chiang Rai & 25 November 2014 & This study \\
\hline Eutypa & E. flavovirens (Pers.) Tul. \& C. Tul. & Decaying twigs & Chiang Rai & 15 November 2012 & Senanayake et al. (2015) \\
\hline
\end{tabular}


Table 4 Continued.

\begin{tabular}{|c|c|c|c|c|c|}
\hline Genera & Species name & Hosts & $\begin{array}{c}\text { Collection site } \\
\text { (Province) }\end{array}$ & Collection date & References \\
\hline \multirow[t]{2}{*}{ Halodiatrype } & H. avicenniae Dayarathne \& K.D. Hyde. & $\begin{array}{l}\text { Intertidal decayed wood of } \\
\text { Avicennia sp. at a mangrove } \\
\text { stand }\end{array}$ & Phetchaburi & 28 August 2015 & Dayarathne et al. (2016) \\
\hline & H. salinicola Dayarathne \& K.D. Hyde. & Submerged marine wood & Phang-Nga & 7 December 2014 & Dayarathne et al. (2016) \\
\hline \multirow[t]{8}{*}{ Peroneutypa } & $\begin{array}{l}\text { P. diminutiasca Q.J. Shang, Phookamsak \& K.D. } \\
\text { Hyde. }\end{array}$ & Undetermined deadwood & Chiang Mai & 27 January 2017 & Shang et al. (2018) \\
\hline & P. longiasca Senwanna, Phookamsak \& K.D. Hyde. & Dead twig of Hevea brasiliensis & Chiang Rai & 1 November 2016 & Senwanna et al. (2017) \\
\hline & P. mackenziei Q.J. Shang, Phookamsak \& K.D. Hyde. & Undetermined decaying wood & Chiang Rai & 22 January 2015 & Shang et al. (2017) \\
\hline & P. rubiformis Q.J. Shang, Phookamsak \& K.D. Hyde. & Undetermined deadwood & Chiang Mai & 27 January 2017 & Shang et al. (2018) \\
\hline & P. scoparia Carmarán \& A.I. Romero. & Dead culms of bamboo & Chiang Rai & 16 July 2011 & Dai et al. (2016) \\
\hline & & Dead culms of bamboo & Chiang Rai & 11 August 2011 & Dai et al. (2016) \\
\hline & & Undetermined deadwood & Chiang Mai & 27 January 2017 & Shang et al. (2018) \\
\hline & & Dieback diseased marine wood & Phetchaburi & 11 January 2018 & Hyde et al. (2019) \\
\hline
\end{tabular}

Table 5 Comparison of the nucleotides of Allocryptovalsa elaeidis to A. polyspora, A. cryptovalsoidea and A. rabenhorstii.

\begin{tabular}{|c|c|c|c|c|c|c|c|}
\hline Allocryptovalsa spp. & LSU & SSU & ITS & TUB2 & RBP2 & tef1 & References \\
\hline A. polyspora MFLUCC17-0364 & $1 / 823(0.12 \%)$ & - & $3 / 486(0.62 \%)$ & $12 / 516(2.32 \%)$ & - & - & Senwanna et al. (2017) \\
\hline A. cryptovalsoidea HVFIG02 & - & - & $4 / 488(0.81 \%)$ & 0 & - & - & Trouillas et al. (2011) \\
\hline A. rabenhorstii WA07CO & - & - & $23 / 560(4.1 \%)$ & 27/369 (7.31\%) & - & - & Trouillas et al. (2011) \\
\hline
\end{tabular}

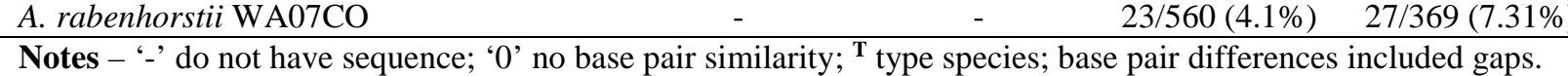

Table 6 Comparison of the nucleotides of Allodiatrype arengae to all species of Allodiatrype, and type species of the genus Diatrype.

\begin{tabular}{|c|c|c|c|c|c|c|c|}
\hline Species & LSU & SSU & ITS & TUB2 & RBP2 & tef1 & References \\
\hline A. elaeidicola MFLUCC 15-0737 & 0 & $1 / 1030(0.09 \%)$ & $13 / 605(2.14 \%)$ & 28/1586 (1.76\%) & $3 / 1139(0.26 \%)$ & 0 & This study \\
\hline A. elaeidis MFLUCC 15-0708 & 0 & 0 & 13/621 (2.09\%) & 16/1579 (1.01\%) & $2 / 1138(0.17 \%)$ & 0 & This study \\
\hline A. thailandica MFLUCC 14-1210 & - & - & 9/526 (1.71\%) & - & - & - & Li et al. (2016) \\
\hline A. thailandica MFLUCC 15-0711 & 0 & 9/1040 (0.86\%) & $11 / 619(1.77 \%)$ & - & - & - & This study \\
\hline Diatrype disciformis $^{\mathbf{T}}$ & $21 / 905(2.32 \%)$ & 2/894 (0.22\%) & 56/536 (10.44\%) & - & $314 / 1137$ (27.6\%) & 69/957 (7.2\%) & Acero et al. (2004) \\
\hline
\end{tabular}

Notes - '-' do not have sequence; ‘0’ no base pair similarity; ${ }^{\mathbf{T}}$ type species of Diatrype; base pair differences included gaps. 
Table 7 Comparison of the nucleotides of Diatrypella elaeidis to D. delodicis, D. heveae, and D. verruciformis.

\begin{tabular}{|c|c|c|c|c|c|c|c|}
\hline Diatrypella spp. & LSU & SSU & ITS & TUB2 & RBP2 & tef1 & References \\
\hline D. delonicis MFLUCC 15-1014 & - & - & $1 / 600(0.16 \%)$ & $7 / 370(1.89 \%)$ & - & - & Hyde et al. (2019) \\
\hline D. heveae MFLUCC 15-0274 & 1/889 (0.11\%) & $6 / 1036(0.57 \%)$ & 10/603 (1.65\%) & 15/810 (1.85\%) & $26 / 800(3.25 \%)$ & 9/954 (0.94\%) & This study \\
\hline D. verruciformis UCROK754 & - & - & 15/607 (2.47\%) & 35/367 (9.53\%) & - & - & Lynch et al. (2013) \\
\hline
\end{tabular}

Notes - ‘-’ do not have sequence; '0’ no base pair similarity; base pair differences included gaps.

\section{Acknowledgments}

We are grateful to the National Research Council of Thailand (project no. 61215320023), the Mushroom Research Foundation and the Thailand Research Fund entitled. The authors extend their appreciation to The Researchers supporting project number (RSP-2019/56) King Saud University, Riyadh, Saudi Arabia. Kevin D. Hyde thanks The future of specialist fungi in a changing climate: baseline data for generalist and specialist fungi associated with ants, Rhododendron species and Dracaena species (grant number: DBG6080013) and Impact of climate change on fungal diversity and biogeography in the Greater Mekong Subregion (grant number: RDG6130001). Saranyaphat Boonmee would like to thank the Thailand Research Fund (No. TRG6180001), Plant Genetic Conservation Project under the Royal Initiation of Her Royal Highness Princess Maha Chakri Sirindhorn-Mae Fah Luang University and Mae Fah Luang University grant Number 631C15001. Rungtiwa Phookamsak thanks CAS President's International Fellowship Initiative (PIFI) for young staff (grant no. 2019FYC0003), The Yunnan Provincial Department of Human Resources and Social Security (grant no. Y836181261), and National Science Foundation of China (NSFC) project code 31850410489 for financial support. Sirinapa Konta is grateful to Ausana Mapook, Dr. Paul Kirk, Dr. Shaun Pennycook, Dr. Saowaluck Tibpromma, Dr. Mingkwan Doilom, Li Junfu, Dr. Samantha C. Karunarathna, Yuanpin Xiao, Li Wenjing, Sirilak Radbouchoom, Zeng Ming, Qiuju Shang, Monika C. Dayarathne, and Milan C. Samarakoon for their valuable suggestion and help.

\section{References}

Acero FJ, González V, Sánchez-Ballesteros J, Rubio V, et al. 2004 - Molecular phylogenetic studies on the Diatrypaceae based on rDNA-ITS sequences. Mycologia 96, 249-259.

Alfieri Jr SA, Langdon KR, Wehlburg C, Kimbrough JW. 1984 - Index of Plant Diseases in Florida (Revised). Florida Department of Agriculture and Consumer Services Division of Plant Industry Bulletin 11, 1-389.

Anonymous. 1960 - Index of Plant Diseases in the United States. U.S.D.A. Agriculture. Handbook. 165, 1-531.

Arhipova N, Gaitnieks T, Donis J, Stenlid J, et al. 2012 - Heart-rot and associated fungi in Alnus glutinosa stands in Latvia. Scandinavian Journal of Forest Research 27, 327-336.

Carmarán CC, Romero AI, Giussani LM. 2006 - An approach towards a new phylogenetic classification in Diatrypaceae. Fungal Diversity $23,67-87$.

Cash EK. 1952 - A record of the fungi named by J.B. Ellis (Part 1). USDA Special publication 2, 1-165.

Chalkley DB, Suh SO, Volkmann-Kohlmeyer B, Kohlmeyer J, et al. 2010 - Diatrypasimilis australiensis, a novel xylarialean fungus from mangrove. Mycologia 102, 430-437. 
Chlebicki A. 1986 -Variability in Diatrypella favacea in Poland. Transactions of the British Mycological Society 86, 441-449.

Ciavatta ML, Lopez-Gresa MP, Gavagnin M, Nicoletti R, et al. 2008 - Cytosporin-related compounds from the marine-derived fungus Eutypella scoparia. Tetrahedron 64, 5365-5369.

Crous PW, Wingfield MJ, Guarro J, Cheewangkoon R, et al. 2013 - Fungal Planet description sheets: 154-213. Persoonia: Molecular Phylogeny and Evolution of Fungi 31, 1-188.

Dai DQ, Phookamsak R, Wijayawardene NN, Li WJ, et al. 2016 - Bambusicolous fungi. Fungal Diversity 82, 1-105.

Dayarathne MC, Phookamsak R, Hyde KD, Manawasinghe IS, et al. 2016 - Halodiatrype, a novel diatrypaceous genus from mangroves with $H$. salinicola and $H$. avicenniae sp. nov. Mycosphere 7, 612-627.

de Almeida DAC, Gusmão LFP, Miller AN. 2016 - Taxonomy and molecular phylogeny of Diatrypaceae (Ascomycota, Xylariales) species from the Brazilian semi-arid region, including four new species. Mycological Progress 15, 1-27.

de Errasti A, Carmarán C, Novas MV. 2010 - Diversity and significance of fungal endophytes from living stems of naturalized trees from Argentina. Fungal Diversity 41, 29-40.

Dingley JM, Fullerton RA, McKenzie EHC. 1981 - Survey of Agricultural Pests and Diseases. Technical Report Volume 2. Records of Fungi, Bacteria, Algae, and Angiosperms Pathogenic on Plants in Cook Islands, Fiji, Kiribati, Niue, Tonga, Tuvalu, and Western Samoa. F.A.O. 485 pages.

Farr ML. 1973 - An annotated list of Spegazzini's fungus taxa, Vol. 1. Bibliotheca Mycologica 35, $1-823$.

Fröhlich J, Hyde KD. 2000 - Palm Microfungi. Fungal Diversity Research. Series 3, 1-393.

Glass NL, Donaldson GC. 1995 - Development of primer sets designed for use with the PCR to amplify conserved genes from filamentous ascomycetes. Applied \& Environmental Microbiology 61, 1323-1330.

Glawe A, Jacobs KA. 1987 - Taxonomic notes on Eutypella vitis, Cryptosphaeria populina, and Diatrype stigma. Mycologia 79, 135-139.

Glawe DA, Jones JP. 1989 - The anamorphs of Diatrypella prominens and Eutypella sabalina. Mycotaxon 34, 277-281.

Glawe DA, Rogers JD. 1982 - Observations on the anamorphs of six species of Diatrype and Diatrypella. Canadian Journal of Botany 60, 245-251.

Glawe DA, Rogers JD. 1984 - Diatrypaceae in the Pacific Northwest. Mycotaxon 20, 401-460.

Glez-Peña D, Gómez-Blanco D, Reboiro-Jato M, Fdez-Riverola F, et al. 2010 - ALTER: programoriented conversion of DNA and protein alignments. Nucleic Acids Research 38, 14-18.

Grassi EM, Pildain MB, Levin LN, Carmaran CC. 2014 - Studies in Diatrypaceae: the new species Eutypa microasca and investigation of ligninolytic enzyme production. Sydowia 66, 99-114.

Helaly SE, Thongbai B, Stadler M. 2018 - Diversity of biologically active secondary metabolites from endophytic and saprotrophic fungi of the ascomycete order Xylariales. Natural Product Reports 35, 992-1014.

Hongsanan S, Maharachchikumbura SSN, Hyde KD, Samarakoon MC, et al. 2017 - An updated phylogeny of Sordariomycetes based on phylogenetic and molecular clock evidence. Fungal Diversity 84, 25-41.

Hongsanan S, Xie N, Liu JK, Dissanayake A, et al. 2018 - Can we use environmental DNA as holotypes? Fungal Diversity 92, 1-30.

Huelsenbeck JP, Ronquist F. 2001 - MRBAYES: Bayesian inference of phylogenetic trees. Bioinformatics 17, 754-755.

Hyde KD, Norphanphoun C, Chen J, Dissanayake AJ, et al. 2018 - Thailand's amazing diversity up to $96 \%$ of fungi in northern Thailand are novel. Fungal Diversity 93, 215-239.

Hyde KD, Tennakoon DS, Jeewon R, Bhat DJ, et al. 2019 - Fungal diversity notes 1036-1152: taxonomic and phylogenetic contributions on genera and species of fungal taxa. Fungal Diversity 96, 1-242. 
Jayasiri SC, Hyde KD, Ariyawansa HA, Bhat J, et al. 2015 - The Faces of Fungi database: fungal names linked with morphology, phylogeny and human impacts. Fungal Diversity 74, 3-18.

Jurc D, Ogris N, Slippers B, Stenlid J. 2006 - First report of Eutypella canker of Acer pseudoplatanus in Europe. Plant Pathology 55, 577-577.

Katoh K, Standley K. 2013 - MAFFT Multiple Sequence Alignment Software Version 7: improvements in performance and usability. Molecular Biology \& Evolution 30, 772-780.

Klaysuban A, Sakayaroj J, Jones EG. 2014 - An additional marine fungal lineage in the Diatrypaceae, Xylariales: Pedumispora rhizophorae. Botanica marina 57, 413-420.

Konta S, Hongsanan S, Tibpromma S, Thongbai B, et al. 2016 - An advance in the endophyte story: Oxydothidaceae fam. nov. with six new species of Oxydothis. Mycosphere 7, 14251446.

Kowalski T, Bednarz B. 2017 - Eutypella parasitica a new pathogen causing cankers on Acer spp. trunks in Poland. Sylwan 161, 630-638.

Kumar S, Stecher G, Tamura K. 2016 - MEGA7: Molecular Evolutionary Genetics Analysis version 7.0 for bigger datasets. Molecular biology and evolution 33, 1870-1874.

Lawrence DP, Travadon R, Nita M, Baumgartner K. 2017 - Trunk Disease ID. org: A molecular database for fast and accurate identification of fungi commonly isolated from grapevine wood. Crop Protection 102, 110-117.

Li GJ, Hyde KD, Zhao RL, Hongsanan S, et al. 2016 - Fungal diversity notes 253-366: taxonomic and phylogenetic contributions to fungal taxa. Fungal Diversity 78, 1-237.

Liu JK, Hyde KD, Gareth EBG, Ariyawansa HA, et al. 2015 - Fungal diversity notes 1 - 110: taxonomic and phylogenetic contributions to fungal species. Fungal Diversity 72, 1-197.

Liu YJ, Whelen S, Hall BD. 1999 - Phylogenetic relationships among ascomycetes: evidence from an RNA polymerase II subunit. Molecular Biology and Evolution 16, 1799-1808.

Lu B, Hyde KD, Ho WH, Tsui KM, et al. 2000 - Checklist of Hong Kong Fungi. Fungal Diversity Research Series 5, 1-207.

Luque J, Garcia-Figueres F, Legorburu FJ, Muruamendiaraz A, et al. 2012 - Species of Diatrypaceae associated with grapevine trunk diseases in Eastern Spain. Phytopathologia Mediterranea 51, 528-540.

Luque J, Sierra D, Torres E, Garcia F. 2006 - Cryptovalsa ampelina on grapevines in NE Spain: identification and pathogenicity. Phytopathologia Mediterranea 45, 101-109.

Lygis V, Vasiliauskas R, Stenlid J. 2004 - Planting Betula pendula on pine sites infested by Heterobasidion annosum: disease transfer, silvicultural evaluation, and community of woodinhabiting fungi. Canadian Journal of Forest Research 34, 120-130.

Lynch SC, Eskalen A, Zambino PJ, Mayorquin JS, et al. 2013 - Identification and pathogenicity of Botryosphaeriaceae species associated with coast live oak (Quercus agrifolia) decline in southern California. Mycologia 105, 125-140.

Maharachchikumbura SSN, Hyde KD, Jones EBG, McKenzie EHC, et al. 2016 - Families of Sordariomycetes. Fungal Diversity 79, 1-317.

Mayorquin JS, Wang DH, Twizeyimana M, Eskalen A. 2016 - Identification, distribution, and pathogenicity of Diatrypaceae and Botryosphaeriaceae associated with Citrus branch canker in the Southern California desert. Plant Disease 100, 2402-2413.

McKenzie EHC, Buchanan PK, Johnston PR. 2004 - Checklist of fungi on nikau palm (Rhopalostylis sapida and $R$. baueri var. chessemanii) in New Zealand. New Zealand Journal of Botany 42, 335-355.

Mehrabi M, Hemmati R, Vasilyeva LN, Trouillas FP. 2015 - A new species and a new record of Diatrypaceae from Iran. Mycosphere 6, 60-68.

Mehrabi M, Hemmati R, Vasilyeva LN, Trouillas FP. 2016 - Diatrypella macrospora sp. nov. and new records of diatrypaceous fungi from Iran. Phytotaxa 252, 43-55.

Mendes MAS, da Silva VL, Dianese JC. 1998 - Fungos em Plants no Brasil. EmbrapaSPI/Embrapa-Cenargen, Brasilia 1-555. 
Miller MA, Pfeiffer W, Schwartz T. 2010 - Creating the CIPRES Science Gateway for inference of large phylogenetic trees. In Gateway Computing Environments Workshop 2010 (GCE), New Orleans, Louisiana, November 2010, 1-8.

Mostert L, Halleen F, Creaser ML, Crous PW. 2004 - Cryptovalsa ampelina, a forgotten shoot and cane pathogen of grapevines. Australasian Plant Pathology 33, 295-299.

Moyo P, Damm U, Mostert L, Halleen F. 2018a - Eutypa, Eutypella, and Cryptovalsa Species (Diatrypaceae) associated with Prunus species in South Africa. Plant Disease 102, 14021409.

Moyo P, Mostert L, Halleen F. 2019 - Diatrypaceae species overlap between vineyards and natural ecosystems in South Africa. Fungal Ecology 39, 142-151.

Moyo P, Mostert L, Spies CF, Damm U, et al. 2018b - Diversity of Diatrypaceae species associated with dieback of grapevines in South Africa, with the description of Eutypa cremea sp. nov. Plant Disease 102, 220-230.

Nitschke TRJ. 1869 - Grundlage eines Systems der Pyrenomyceten. Verhandlungen des Naturhistorischen Vereins der Preussischen Rheinlande, Westfalens und des Regierungsbezirks Osnabrück 262, 70-77.

Nylander JAA. 2004 - MrModeltest v2.2. Program distributed by the author: 2. Evolutionary Biology Centre, Uppsala University 1-2.

O’Donnell K, Cigelnik E. 1997 - Two divergent intragenomic rDNA ITS2 types within amonophyletic lineage of the fungus Fusarium are nonorthologous. Molecular Phylogenetics and Evolution 7, 103-116.

Paolinelli-Alfonso M, Serrano-Gomez C, Hernandez R. 2015 - Occurrence of Eutypella microtheca in grapevine cankers in Mexico. Phytopathologia Mediterranea 54, 86-93.

Patil MS, Patil SD. 1983 - Studies in Pyrenomycetes of Maharashtra II. Genus Diatrype. Indian Journal of Mycology and Plant Pathology 13, 134-142.

Peršoh D, Melcher M, Graf K, Fournier J, et al. 2009 - Molecular and morphological evidence for the delimitation of Xylaria hypoxylon. Mycologia 101, 256-268.

Petrak F. 1953 - Ein Beitrag zur Pilzflora Floridas. Sydowia 7, 103-116.

Phookamsak R, Hyde KD, Jeewon R, Bhat DJ, et al. 2019 - Fungal diversity notes 929-1036: taxonomic and phylogenetic contributions on genera and species of fungal taxa. Fungal Diversity 95, 1-273.

Pitt WM, Trouillas FP, Gubler WD, Savocchia S, et al. 2013 - Pathogenicity of diatrypaceous fungi on grapevines in Australia. Plant Disease 97, 749-756.

Rambaut A. 2006 - FigTree: Tree Figure Drawing Tool Version 1.4.0 2006-2012, Institute of Evolutionary Biology, University of Edinburgh. http://tree.bio.ed.ac.uk/software/figtree/.

Rappaz F. 1987 - Taxonomy and nomenclature of the octosporous Diatrypaceae. Mycologia Helvetica 2, 285-648.

Rehner SA, Buckley E. 2005 - A Beauveria phylogeny inferred from nuclear ITS and EF1- $\alpha$ sequences: evidence for cryptic diversification and links to Cordyceps teleomorphs. Mycologia 97, 84-98.

Reinking OA. 1919 - Host Index of Diseases of Economic Plants in the Philippines. Philippine Agricultural Scientist 8, 38-54.

Reinking OA.1918 - Philippine economic plant diseases. Philippine Journal of Science 13, 165274.

Rolshausen PE, Baumgartner K, Travadon R, Fujiyoshi P, et al. 2014 - Identification of Eutypa spp. causing Eutypa dieback of grapevine in eastern North America. Plant Disease 98, 483491.

Rolshausen PE, Mahoney NE, Molyneux RJ, Gubler WD. 2006 - A reassessment of the species concept in Eutypa lata, the causal agent of Eutypa dieback of grapevine. Phytopathology 96, 369-377.

Saccardo PA. 1882 - Sylloge fungorum omnium hucusque cognitorum (Vol. 1). sumptibus auctoris 190p. 
Samarakoon MC, Hyde KD, Promputtha I, Ariyawansa HA, et al. 2016 - Divergence and ranking of taxa across the kingdoms Animalia, Fungi and Plantae. Mycosphere 7, 1678-1689.

Senanayake IC, Maharachchikumbura SN, Hyde KD, Bhat JD, et al. 2015 - Towards unraveling relationships in Xylariomycetidae (Sordariomycetes). Fungal Diversity 73, 73-144.

Senwanna C, Phookamsak R, Doilom M, Hyde KD, et al. 2017 - Novel taxa of Diatrypaceae from Para rubber (Hevea brasiliensis) in northern Thailand; introducing a novel genus Allocryptovalsa. Mycosphere 8, 1835-1855.

Shang QJ, Hyde KD, Jeewon R, Khan S, et al. 2018 - Morpho-molecular characterization of Peroneutypa (Diatrypaceae, Xylariales) with two novel species from Thailand. Phytotaxa 356, 1-18.

Shang QJ, Hyde KD, Phookamsak R, Doilom M, et al. 2017 - Diatrypella tectonae and Peroneutypa mackenziei spp. nov. (Diatrypaceae) from northern Thailand. Mycological progress 16, 463-476.

Silvestro D, Michalak I. 2011 - raxmlGUI: a graphical front-end for RAxML. Organisms Diversity \& Evolution 12, 335-337.

Stamatakis A. 2006 - RAxML-VI-HPC: maximum likelihood-based phylogenetic analyses with thousands of taxa and mixed models. Bioinformatics 22, 2688-2690.

Sung GH, Sung JM, Hywel-Jones NL, Spatafora JW. 2007 - A multi-gene phylogeny of Clavicipitaceae (Ascomycota, Fungi): identification of localized incongruence using a combinational bootstrap approach. Molecular Phylogenetics and Evolution 44, 1204-1223.

Tai FL. 1979 - Sylloge Fungorum Sinicorum. Science. Press, Academica Sinica, Peking 1-1527.

Taylor JE, Hyde KD. 2003 - Microfungi of Tropical and Temperate Palms. Fungal Diversity Research Series 12, 1-459.

Teng SC. 1996 - Fungi of China. Mycotaxon, Ithaca, NY 1-586.

Teodoro NG. 1937 - An Enumeration of Philippine Fungi. Technical Bulletin Department of Agriculture \& Commerce Manila 4, 1-585.

Trouillas FP, Gubler WD. 2004 - Identification and characterization of Eutypa leptoplaca, a new pathogen of grapevine in Northern California. Mycological Research 108, 1195-1204.

Trouillas FP, Gubler WD. 2010 - Host range, biological variation, and phylogenetic diversity of Eutypa lata in California. Phytopathology 100, 1048-1056.

Trouillas FP, Hand FP, Inderbitzin P, Gubler WD. 2015 - The genus Cryptosphaeria in the western United States: taxonomy, multilocus phylogeny and a new species, C. multicontinentalis. Mycologia 107, 1304-1313.

Trouillas FP, Pitt WM, Sosnowski MR, Huang R, et al. 2011 - Taxonomy and DNA phylogeny of Diatrypaceae associated with Vitis vinifera and other woody plants in Australia. Fungal Diversity 49, 203-223.

Trouillas FP, Úrbez-Torres JR, Gubler WD. 2010 - Diversity of diatrypaceous fungi associated with grapevine canker diseases in California. Mycologia 102, 319-336.

U'Ren JM, Miadlikowska J, Zimmerman NB, Lutzoni F, el al. 2016 - Contributions of North American endophytes to the phylogeny, ecology, and taxonomy of Xylariaceae (Sordariomycetes, Ascomycota). Molecular Phylogenetics and Evolution 98, 210-232.

Úrbez-Torres JR, Adams P, Kamas J, Gubler WD. 2009 - Identification, incidence, and pathogenicity of fungal species associated with grapevine dieback in Texas. American Journal of Enology and Viticulture 60, 497-507.

Úrbez-Torres JR, Peduto F, Striegler RK, Urrea-Romero KE, et al. 2012 - Characterization of fungal pathogens associated with grapevine trunk diseases in Arkansas and Missouri. Fungal Diversity 52, 169-189.

Úrbez-Torres JR, Peduto F, Vossen PM, Krueger WH, el al. 2013 - Olive twig and branch dieback: etiology, incidence, and distribution in California. Plant Disease 97, 231-244.

Urtiaga R. 1986 - Indice de enfermedades en plantas de Venezuela y Cuba. Impresos en Impresos Nuevo Siglo.S.R.L., Barquisimeto, Venezuela 1-202. 
Verma RK. 1996 - Some new records of fungi associated with salfi palm (Caryota urens). Indian Phytopathology 49, 22-25.

Vieira MLA, Hughes AFS, Gil VB, Vaz ABM, et al. 2011 - Diversity and antimicrobial activities of the fungal endophyte community associated with the traditional Brazilian medicinal plant Solanum cernuum Vell. (Solanaceae). Canadian Journal of Microbiology 58, 54-56.

Vilgalys R, Hester M. 1990 - Rapid genetic identification and mapping of enzymatically amplified ribosomal DNA from several Cryptococcus species. Journal of Bacteriology 172, 4238-4246.

Vizioli J. 1923 - Some Pyrenomycetes of Bermuda. Mycologia 15, 107-119.

White TJ, Bruns T, Lee SJWT, Taylor JW. 1990 - Amplification and direct sequencing of fungal ribosomal RNA genes for phylogenetics. PCR protocols: a guide to methods and applications 18, 315-322.

Wijayawardene NN, Hyde KD, Rajeshkumar KC, Hawksworth DL, et al. 2017a - Notes for genera: Ascomycota. Fungal Diversity 86, 1-594.

Wijayawardene NN, Hyde KD, Tibpromma S, Wanasinghe DN, et al. 2017b - Towards incorporating asexual fungi in a natural classification: checklist and notes 2012-2016. Mycosphere 8, 1457-1554.

Zhuang WY Ed. 2001 - Higher Fungi of Tropical China. Mycotaxon, Ithaca, NY 1-485. 